\title{
Activities of Daily Living and Associated Costs in the Most Widespread Neurodegenerative Diseases: A Systematic Review
}

This article was published in the following Dove Press journal:

Clinical Interventions in Aging

\section{Petra Maresova $\mathbb{D}^{1}$ \\ Jan Hruska $\mathbb{D}^{\prime}$ \\ Blanka Klimova $\mathbb{1}^{2}$ \\ Sabina Barakovic (1D) ${ }^{3}$ \\ Ondrej Krejcar $\mathbb{D}^{4}$}

'Department of Economics, Faculty of Informatics and Management, University of Hradec Kralove, Hradec Kralove 500 03, Czech Republic; '2Department of Applied Linguistics, Faculty of Informatics and Management, University of Hradec Kralove, Hradec Kralove 500 03, Czech Republic; ${ }^{3}$ Faculty of Transport and Communications, University of Sarajevo, Sarajevo 71000, Bosnia and Herzegovina; ${ }^{4}$ Center for Basic and Applied Science, Faculty of Informatics and Management, University of Hradec Kralove, Hradec Kralove 500 03, Czech Republic
Correspondence: Ondrej Krejcar Center for Basic and Applied Science, Faculty of Informatics and Management, University of Hradec Kralove,

Rokitanskeho 62/26, Hradec Kralove 500

03, Czech Republic

Tel +420 777484280

Email ondrej.krejcar@uhk.cz

\begin{abstract}
Nowadays, the population is rapidly ageing because of increasing life expectancy and decreasing birth rates. Thus, the purpose of this systematic review is to prepare a comprehensive overview which identifies the activities of daily living (ADLs) that are gradually reduced among patients with dementia, as well as explore the therapies applied in relation to dementia and how they effectively improve the quality of life (QoL) of patients and caregivers. Furthermore, we aim to summarise the ADL activities influenced by therapies and examine the treatment costs and care for patients so that recommendations for research and development (R\&D) can be made to improve both the QoL of people with dementia and cost-saving measures. The research focuses on four selected neurodegenerative diseases: Alzheimer, Parkinson, vascular dementia, and amyotrophic lateral sclerosis. Therefore, the peer-reviewed English written articles from 2014 to 2019 were searched between September 1 and December 13, 2019. Twenty-seven papers were included in the analysis. The results show that essential assistance occurs in connection with activities: eating, drinking, dressing, bathing, personal hygiene, use of the toilet, and transport. By contrast, shopping or cleaning is not addressed as much. A lower ability to take care of oneself is connected with poor patient health and higher social care costs because the patient requires care from external sources, such as home aid or nurse visits. The challenge that remains is to shift new knowledge from scientific disciplines and connect it with the needs of patients to remove legitimate barriers and increase the acceptance of new solutions by popularisation. Additionally, regarding the burden on caregivers, it would be appropriate to promote this area of education and employment so that family members can use formal caregivers, ensuring them free time and much-needed rest.
\end{abstract}

Keywords: costs, neurodegenerative diseases, quality of life, activities of daily living

\section{Introduction}

Present demographic trends indicate that the population is ageing. The World Health Organization (WHO) and United Nations (UN) statistics show that the population at the age of $60+$ years will increase from less than 1 million in 2020 to 2 million by $2050 .^{1,2}$ The projections also show that the number of elderly individuals will be 1.5 billion by 2050, that is, twofold more than in $2020 .^{3}$ Such a demographic change results in various economic and social issues, as well as an increase in ageing illnesses, such as dementia, ${ }^{4,5}$ of which there are over 50 million cases.

Dementia is a neurodegenerative disorder that usually starts with cognitive decline, that is, deterioration of memory and thinking skills. These symptoms are 
usually accompanied or preceded by behavioural and social changes. ${ }^{6}$ For these reasons, patients with dementia are limited to executing activities of daily living (ADLs), caring about themselves, and being fully dependent on the help of their caregivers, who are in $80 \%$ of cases their relatives. $^{7}$ This impacts the patients' lives and those of their caregivers, who are burdened mentally, socially, and economically because they often have to give up their regular jobs. On average, family caregivers spend 47 hours per week looking after their affected family members. Two thirds of these caregivers are women, and 34\% of caregivers are aged $65+$ years. ${ }^{7}$ Thus, the total costs of dementia include not only medications and patients' treatment but also caregivers' care. As the WHO (2017) states, "in 2015, the total global societal cost of dementia was estimated to be US\$ 818 billion, equivalent to $1.1 \%$ of global gross domestic product (GDP)". ${ }^{8}$

Unfortunately, governments worldwide do not fully realise the scope of the aforementioned issues. The absence of the interconnection of areas from individual research domains that seek to support a higher quality of life (QoL) for patients and caregivers, such not medical and technical research directions, and a lack of legal measures protecting the rights of patients with dementia, should be addressed to ensure relevant QoL for these target groups. Additionally, an important issue that lacks focus is the prominent economic aspect of caring for patients with dementias and in general the economic potential of older adults with dementia and their caregivers. Additionally, as discussed in Baraković et $\mathrm{al}^{9}$ to ensure the sustainable development of a society where average age is expected to continue to increase to be quite high and the number of persons struggling with dementia is respectable, society must provide a high QoL for these patients and their caregivers. To achieve these goals, aspects, and activities of everyday life for older adults and their caregivers must be investigated.

In addition to weak institutional responses to these issues, the current research and reviews related to ADLs in dementia (which are addressed in the sections below) have mostly ignored the impact of the cost and analysis of therapy on QoL improvement. More precisely, the reviewed studies have usually focused on one disease and the associated direct, indirect, and societal costs. ${ }^{10}$ Even when they have included more than one neurodegenerative disease and assessed their costs, they have not gone deeper to analyse individual therapies. ${ }^{11,12}$ Some of this research has only described individual ADLs activities connected with a particular neurodegenerative disease ${ }^{13}$ or offered methodological approaches to tackling these issues (e.g. ref. 28).

Motivated by the aforementioned literature review, this review study attempted to build on the existing reviews by focusing on all activities that require caregivers' assistance and other related services in the context of economic burden, with the aim of improving QoL. Therefore, this systematic review has two aims in terms of improving QoL. The first aim is to prepare a comprehensive overview that identifies the ADLs activities that are gradually reduced among patients in dementia, as well as explore the therapies applied in relation to dementia and how they are effective in attempting to improve QoL. These activities can be described as ADLs because they include all the tasks for daily self-care, such as feeding, bathing, toileting, shopping, and leisure activities. Furthermore, each patient with a dementia progresses at a different rate; patients suffer from slightly different symptoms and require different help in terms of human resources, services, and medical devices. This study concentrates on four selected dementias prevalent in the central European context: Alzheimer's disease (AD), vascular dementia (VaD), Parkinson's disease dementia (PDD), and amyotrophic lateral sclerosis (ALS). The second aim is to summarise the ADL activities influenced by therapies and examine the treatment costs and care for patients so that recommendations for $\mathrm{R} \& \mathrm{D}$ can be made to improve both the QoL of people with dementia and cost-saving measures.

After a brief introduction of the topic, the paper is organised as follows: Section 2 provides the theoretical background on the basic specifications of dementia in relation to activities of everyday living, QoL in the context of everyday activities, and potential approaches to improve QoL through ADLs. Section 3 presents a detailed explanation of the search strategy, inclusion and exclusion criteria, and limitations of the review. Results are provided in Section 4, and Section 5 discusses the obtained results. Section 6 provides concludes.

\section{Theoretical Background}

This section provides information on the basic terms that we used as key search terms for detecting the most relevant research studies for this systematic review.

\section{Basic Specifications of Dementia in Relation to Activities of Everyday Living}

Dementia refers to acquired progressive impairment of memory and other cognitive functions that cause a 
significant reduction in social, work, and day-to-day activities. In dementia, behavioural and mood disorders (behavioural and psychological symptoms of dementia; BPSD) may occur in addition to cognitive changes. The most common are irritability, aggression or, conversely, apathy, anxiety, and depression, as well as sleep disorders, food intake, and sexual behaviour. ${ }^{14}$

Generally, the most important proven risk factors for dementia include higher age, female gender, positive family history, high blood pressure, recurrent brain traumas, genetic factors, and lower levels of education. Other risk factors may include a history of myocardial infarction, stroke and generally vascular risk factors, depression or personality disorders, and poor socioeconomic background. ${ }^{14}$

There are three stages of dementia: early (i.e. symptoms such as forgetfulness are not striking), middle (symptoms, e.g. disorientation, behavioural changes, or needing personal assistance, are becoming restricting), and late (i.e. symptoms are obvious, and patients are dependent on the help of other people). ${ }^{8}$ Several forms of the disease exist, and a person may suffer from more than one because dementias can coexist. The most frequent disease is $\mathrm{AD}$, followed by vascular and lewy bodies dementia. PDD or FTD (i.e. frontotemporal degeneration or dementia) are also common, as well as mixed dementia. ${ }^{15}$ Dementia also involves diseases such as ALS, a type of dementia that does not affect cognitive functions as severely as other types. ALS is essentially a dementia type that does not include $\mathrm{AD}$ and instead is marked by motor neuron disease and frontotemporal breakdown. ${ }^{16}$

Within the aforementioned goal, the authors focus on the most common types of dementia, namely, AD, PDD, $\mathrm{VaD}$, and ALS, that are also associated with an aged population.

As aforementioned, the most frequently diagnosed of these diseases is $\mathrm{AD}$ : $5 \%$ of older adults at the age of 65 years, and at the age of 85 years, half of the population. Rarely, autosomal dominant inheritance occurs in families, with $\mathrm{AD}$ beginning at an early age (40-50 years). ${ }^{17}$

Parkinson's disease (PD) is one of the so-called synucleinopathies, namely, proteinopathies, which are characterised by the pathological deposition of the $\alpha$-synuclein protein in neurons and glia in specific areas of the cortex and subcutaneous regions. In PD, mild-grade cognitive impairment is often observed early in the disease and may progress to dementia in up to $80 \%$ of late-stage patients. ${ }^{18,19}$ The risk of developing dementia in patients with PD is 1.7-5.9 times higher than that of the average population of the same age, education, and sex. The risk factors of PD include patient age (rather than age at onset of the disease), severity of Parkinson's syndrome (especially akinesia and axial symptoms), low educational attainment, familial dementia, the presence of medication-induced psychotic disorder, the male gender, and according to some studies, depression. ${ }^{20}$

Vascular Dementia - Diagnostic Criteria lists the names for this type of dementia due to vascular changes, for example, arteriosclerotic dementia, multi-infarct dementia (Hachinski et al 1974), stroke, VaD, cerebrovascular dementia, ischaemic-VAD, or vascular-ischaemic dementia. $\mathrm{VaD}$ is a cognitive disorder caused by necrosis (heart attack) of the brain in vascular disease, including hypertension. The disease occurs at an older age and usually has a sudden onset. Impaired mental function tends to be uneven according to the areas affected by the infarction. Therefore, memory loss, impaired intellect, and focal neurological findings may occur along with good insight and judgement. There is still no agreement on its terminology, classification, and diagnostic criteria. The statistical data reveal that between $6 \%$ and $10 \%$ of individuals aged $65+$ years have dementia and up to $60 \%$ of patients with $\mathrm{AD}$ might also have VaD. ${ }^{21}$

Lou Gehrig's disease or ALS, namely, amyotrophic lateral sclerosis, is a fatal, progressive neurogenerative illness that impacts motor neurons by virtue of the spinal cord or brain. It results in a degradation of the brain and spine, that is, the upper and lower motoneurons or cells that effectively control and influence how muscles move. As a result, there is a gradual muscle weakness to atrophy. Eventually, there is complex paralysis of the whole body while the mind remains intact. The causes of the disease have not yet been sufficiently clarified. The incidence of this disease is approximately two people 100,000 per year, and the prevalence is more or less the same for the Western countries. The average age of ALS onset is 60 years old.

The aforementioned information on these diseases means that individuals suffering from dementia require a complex care for their psychological, social, and biomedical needs. ${ }^{8}$ For instance, they need housing adjustments to perform their ADLs or help with transport. However, most of these requests have not been addressed, and many individuals with dementia are undiagnosed. ${ }^{21}$ Additionally, one fifth of caregivers suffer from mental disorders. $^{22}$ 


\section{Quality of Life: The Ability to Perform Activities of Daily Living}

The limitations of patients with dementia and the scope of care raise related questions on the QoL of both patients and caregivers. Clark described this as "adding life to years rather than years to life". ${ }^{23}$ The main focus in dementia care has become to promote well-being and maintain an optimal QoL.

There are many definitions of QoL. Some studies have described it as follows: ${ }^{24}$ "A perception of one's position in life in the context of culture and value systems in which they live and in relation to their goals, expectations, standards, and concerns"; some as well-being. ${ }^{25}$

A state of well-being which is a composite of two components: 1) the ability to perform everyday activities which reflect physical, psychological, and social well-being, and 2) patient satisfaction with levels of functioning and the control of disease- and/or treatment-related symptoms.

Others have employed the phrase satisfaction with life. ${ }^{26}$ "QoL is the degree of need and satisfaction within the physical, psychological, social, activity, material, and structural area". Thus, QoL can be defined in terms of a multidimensional concept and personal contentment with life. ${ }^{27}$

As per the European framework $8+1,{ }^{28}$

QoL consists of the following eight categories: (i) material living conditions, (ii) health, (iii) education, (iv) productive and valued activities, (v) governance and basic rights, (vi) leisure and social interactions, (vii) natural and living environment, (viii) economic and physical safety, and (ix) overall experience of life.

Although QoL is related to disability, they should be distinguished. ${ }^{29}$ The most broadly adopted definition of disability is from United Nations Convention on the Rights of Persons with Disabilities (UNCRPD):

Persons with disabilities include those who have long-term physical, mental, intellectual or sensory impairments which in interaction with various barriers may hinder their full and effective participation in society on an equal basis with others. ${ }^{30}$

This definition implies that people with disabilities, especially older people, experience more restrictions in ADLs then healthy people, which results in poor QoL.

A basic precondition of independent and high QoL is good health status. An important indicator of the health status of older people is the prevalence and degree of functional disability - dysaptibility—defined as an individual's inability to exercise while performing an age-appropriate activity, and that increases with age. ${ }^{28}$ The deteriorating health of an ageing individual and advanced age can adversely affect their level of self-sufficiency to such an extent that they will no longer be able to perform the activities that provide them with their daily needs and care for themselves - they may lose their self-sufficiency. Therefore, it is crucial to assess an individual's functional status, including an assessment of basic ADLs and instrumental activities of daily living (IADLs), mobility, cognitive abilities, sight and hearing, voiding, nutritional status, and environmental factors.

Basic ADLs (basic self-service routine activities) are common essential activities and tasks performed during the day. They include self-service tasks such as eating, drinking, dressing, washing and bathing, walking and moving, and the ability to hold urine and faeces. Testing and assessing basic daily activities helps determine the needs of the daily personal care of seniors and their long-term care plans. IADLs are activities necessary for living in an independent household and in the community, such as the ability to prepare meals, conduct purchases, conduct simpler household chores, make telephone calls, travel, use medicines, and manage finances (Table 1). Their assessment helps evaluate the type and extent of assistance necessary to ensure a senior's independent or partially dependent life in his or her natural environment. ${ }^{31}$

Table I Activities of Daily Living Overview

\begin{tabular}{|c|c|}
\hline Activities of Daily Living (ADLs) & $\begin{array}{l}\text { Instrumental Activities } \\
\text { of Daily Living (IADLs) }\end{array}$ \\
\hline $\begin{array}{l}\text { Individual hygiene Washing, brushing } \\
\text { teeth, getting dressed, nail and hair care } \\
\text { Continence management A person's } \\
\text { mental and physical capability to } \\
\text { appropriately use the bathroom } \\
\text { Dressing A person's capability to } \\
\text { choose and wear the appropriate } \\
\text { clothes for various purposes } \\
\text { Maintaining food A person's capability } \\
\text { of feeding herself/himself } \\
\text { Ambulating The degree of a person's } \\
\text { capability to move from one position } \\
\text { to the other and to stroll on one's own }\end{array}$ & $\begin{array}{l}\text { Managing a household } \\
\text { Managing medications } \\
\text { Communicating with others } \\
\text { Managing finances }\end{array}$ \\
\hline
\end{tabular}


In other words, ADLs and IADLs are measures of disability deteriorating the QoL. There is no general consensus on the evaluation of QoL. Some of the literature considers self-reporting as the most feasible option in $\mathrm{QoL}$ evaluation, whereas others prefer proxy reports because of their valid data. ${ }^{23}$ In case of dementia, a self-report is not possible because dementia affects cognitive abilities; thus, people with dementia are unreliable sources of information on their QoL. Therefore, many dementia-specific QoL instruments have been developed. Ettema et al identified six dementia-specific QoL measures. ${ }^{32}$ The first instrument is Dementia Care Mapping, an audit tool to evaluate the quality of care of facilities. The other instruments are based on caregiver reports: Alzheimer's Disease Related Quality of Life and Quality of Life for Dementia. The Quality of Life in Alzheimer's Disease (QoL-AD) relies on both patient and caregiver reports to evaluate QoL, and the Dementia Quality of Life (D-QoL) instruments depend on a patient's self-report. In addition, the Cornell-Brown Scale for Quality of Life in Dementia was developed by modifying an instrument to evaluate negative affect. Finally, recent research studies have used the DEMQOL and DEMQOL-Proxy, which are based on self-reports and informant reports, respectively, for evaluating QoL of people with dementia. ${ }^{33-35}$ Nevertheless, further clarification and the development of dementia-specific QoL instruments are still required. ${ }^{32}$

\section{Potential Approaches to Improve QoL in Relation to ADLs}

There have been many efforts and activities to manage the decline in QoL in people with dementia, ranging from individual therapies to solving the issue of nutrition, and from physical activity to patented ICT solutions. ${ }^{31}$

Woods et $\mathrm{al}^{36}$ focused on assessing and comparing individual studies on the effect of reminiscence treatment on patients with dementia. The evaluation of the studies provided insights into the beneficial effects of reminiscence treatment on the mood, well-being, and behaviour of patients with dementia.

Another possibility to increase QoL not only for patients but for seniors is physical activity. In research studies, ${ }^{37}$ the authors have worked with the assumption that physical activity helps improve not only the physical state but also the mental state. Physical activity in people with dementia favourably affects not only mental well- being but also physical performance, cognitive abilities, and social interaction. ${ }^{38}$

Furthermore, the hypothesis on the effect of nutrition on improving the condition of people with dementia was tested. This hypothesis is not based on the assumption that food alone increases patients' QoL, because there is no change in diet but in eating habits. The premise is that people with dementia may forget to eat because of the disease. This decrease in food intake can lead to dehydration and malnutrition and thus deterioration in overall health. $^{39}$

A number of other areas can be found. ICT solutions can also help with many areas and approaches, including those aforementioned. According to Maresova et $\mathrm{al}^{31}{ }^{31} \mathrm{a}$ patent database search revealed that there may be multiple solutions with respect to these diseases. To help elderly individuals suffering from chronic diseases, ICT researchers should focus on making technologies user-friendly, safe and secure, or affordable in terms of price.

As Klimova et al indicated, a combination of all the aforementioned approaches mentioned might be efficient in the delay or maintenance of cognitive disorders in older individuals. $^{6}$

However, in the case of most progressive cognitive disorders, no treatment that stops or slows their progression. However, there are drug treatments that may manage the symptoms. ${ }^{40}$ For example, the same drugs used to treat $\mathrm{AD}$ may be used to improve the symptoms of other types of dementias. ${ }^{41}$ In addition, several dementia symptoms may be treated by using non-drug approaches, such as occupational therapy, ${ }^{42}$ and psycho-social interventions, such as cognitive stimulation therapy. ${ }^{43}$ Randomised controlled trials have demonstrated that such approaches can be beneficial in improving the cognition and QoL of people with dementia and their caregivers. ${ }^{44,45}$ Finally, caregivers' support is crucial in dementia treatment; thus, the instruments to facilitate dialogue between caregivers and professionals with the aim of assessing their needs should be developed. ${ }^{46}$ Finally, the path to effective treatments of dementia is through increased research funding and increased participation in clinical studies.

\section{Methods}

\section{Study Design}

We conducted a methodological systematic review and followed the standard Preferred Reporting Items for Systematic Review and Meta-Analysis (PRISMA) 
guidelines. ${ }^{47}$ In this review-based study, we adopted the bibliometric mapping study method $^{48}$ and review technique ${ }^{49}$ based on PRISMA guidelines ${ }^{47}$ to provide a systematic, holistic review of the ADLs activities and therapies among patients with dementia and examine the treatment costs and care for patients so that recommendations for R\&D could be made to improve both the QoL of people with dementia and cost-saving measures. The combination of these two methods could facilitate a deeper understanding of the topic, as well as enable the production of an intellectual mapping structure. ${ }^{48}$

\section{Eligibility Criteria}

We included all reports describing ADLs, therapies, and related costs related to $\mathrm{AD}, \mathrm{PD}, \mathrm{VaD}$, and ALS and the different stages and types of these diseases. We conducted a review of articles published since 2014 (i.e. when 'The Glasgow Declaration 2014' was launched). ${ }^{50}$ The Glasgow Declaration calls for the creation of a European Dementia Strategy and national strategies in every country in Europe. The signatories also call on world leaders to recognise dementia as a public health priority and develop a global action plan on dementia. We restricted inclusion to the English language. A detailed description of the exclusion and inclusion criteria is as follows:

\section{Inclusion Criteria}

- Published from 2014 to 2019-inclusive.

- English-written peer-reviewed full-text articles.

- Focused on costs associated with the treatment of selected neurodegenerative diseases (AD, PD, VaD, ALS).

- Studies that described direct and indirect costs.

- The objective was to explore the present state of the day-to-day activities related to the selected diseases (ADLs and IADLs).

- The purpose was to reveal the present state of the costs and economic burden related to the selected diseases.

- Focused on AD, PD, VaD, and ALS and the different stages and types of these diseases.

- Described the used therapies in long-term care for people with dementia.

\section{Exclusion Criteria}

- A language other than English.

- Main focus of the article was on neurodegenerative disease other than $\mathrm{AD}, \mathrm{PD}, \mathrm{VaD}$, or ALS
- Reviewed studies, meta-analyses, purely descriptive articles, or conference notes.

- Articles with non-related health topics and those that considered the technology used, for example, in drug development or testing new drugs.

- Article focused on trial, CUA, COI studies.

- Papers without an abstract or only the abstract was available.

- Articles on medical devices.

- Aimed at the manufacturing of technological results.

- Analysed the behaviour of caregivers, psychological aspects of informal care, or home care.

- Focused only on health care.

\section{Information Sources and Search Strategy}

The literature review was performed from 1 September 2019 to 13 December 2019 for peer-reviewed, published research studies in English. Two researchers independently reviewed titles and abstracts and reviewed full articles. The studies had to be indexed in WoS and MEDLINE. The search included "Alzheimer", "Parkinson", "Vascular dementia", "Amyotrophic lateral sclerosis", "Long-term care", and "Activity of daily living" from 2014 to 2019 (Table 2). We received 1378 publications; 151 publications were removed due to duplicates and articles written in languages other than English. By filtering out inappropriate publications by keywords and title, we removed 778 publications from the selection. The steps used are as follows:

- Deletion of publications after abstract reading such that 344 publications were removed after reading the abstract

- Examined the entire text of 122 publications

- Removed 24 publications for non-reporting of patient activities

Table 2 Distribution of Examined Articles

\begin{tabular}{|l|l|l|}
\hline $\begin{array}{l}\text { Key Words Used “AND” Between All } \\
\text { Words }\end{array}$ & WoS & PubMed \\
\hline Alzheimer long-term care & 155 & 34 \\
Parkinson long-term care & 101 & 22 \\
Vascular dementia long-term care & 6 & 3 \\
Amyotrophic lateral sclerosis long-term care & 19 & 42 \\
Alzheimer activity of daily living & 363 & 103 \\
Parkinson activity of daily living & 344 & 99 \\
Vascular dementia activity of daily living & 23 & 20 \\
Amyotrophic lateral sclerosis activity of daily living & 12 & 32 \\
Total & 1023 & 355 \\
\hline
\end{tabular}


- Removed 19 publications from selection for nontreatment costs

- Removed 35 publications with a main focus other than treatment, cost, and day-to-day activities
- Of the 1378 publications from Step 1, 27 remained to be analysed (Figure 1).

The general procedure is illustrated in Figure 2.

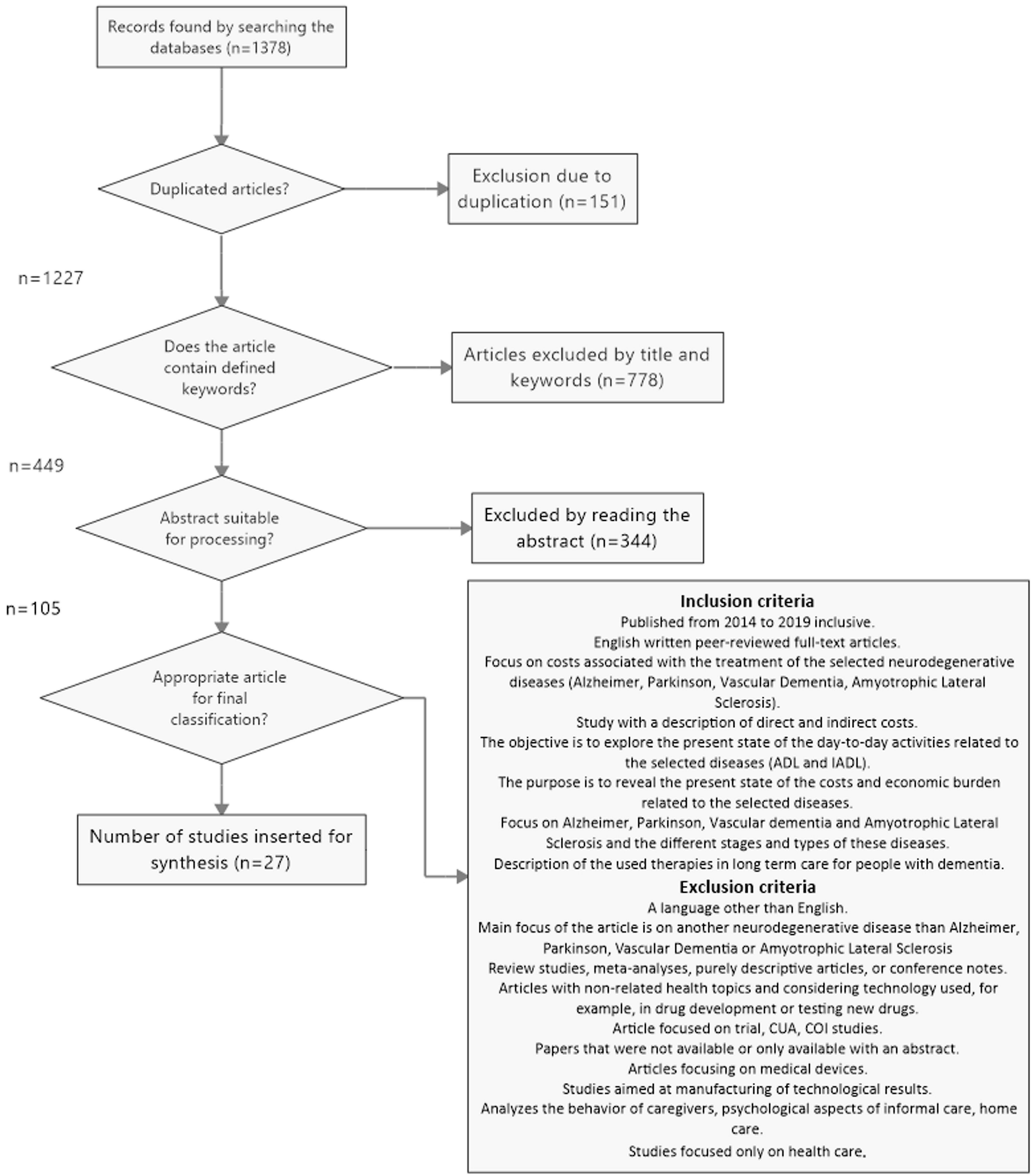

Figure I Process of filtering articles. 


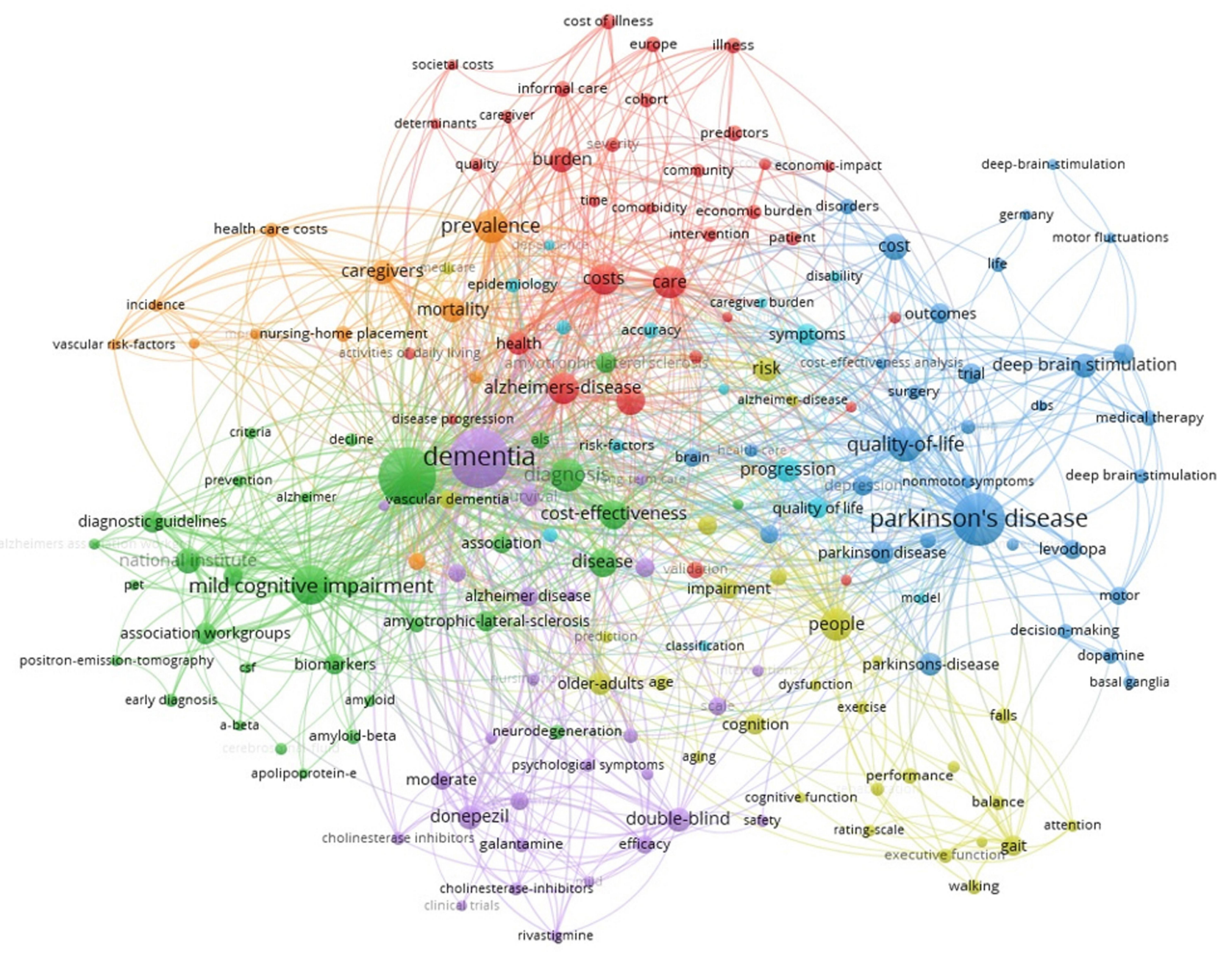

Figure 2 Cluster analysis of selected articles for research.

\section{Cluster Analysis}

To identify the key variable and important keywords in this research area, cluster analysis was performed (Figure 2).

The purpose of the cluster analysis was to identify associations among the main keywords in the selected articles and find correlations and dependencies inside smaller groups of keywords - clusters. The results point to key variables observed across dementia. These are grouped as health care cost-related keywords in two clusters represented by the main keyword, namely, care, costs, caregivers, mortality, prevalence, coloured by red and orange (Figure 2). The next cluster is related to the main keyword-dementiawhich is connected to donepezil as the main medicament and also to efficiency (using the medicament), or, for example, cholinesterase-inhibitor as the component of medicaments where chemical research is in progress. The green cluster represents diagnostics of dementia, such as guidelines, biomarkers, PET, mild cognitive impairment, and criteria. The yellow cluster is related to people and is on the border between dementia diseases and specific disease -PD. This cluster is specific for the orientation in cognitive functions (keyword cognition), exercise, balance, walking, and falls, connected to older adults, and ageing. The last cluster is blue - managing Parkinson disease - with QoL, decision-making, progression, and modelling, and a medical therapy (e.g. deep brain stimulation).

These clusters and structures are not new and have been used in many articles on this topic. Additional information can be found by analysing the turquoise cluster, which is unfortunately spread over almost all the parts of the cluster. The keywords grouped in this cluster are QoL, progression, accuracy, or epidemiology. These are critical key keywords to model QoL, progression, cost-effectiveness, and prevalence. In relation to the aim of the article and related to our cluster analysis, the results of the 
variables in Table 3 were then selected for the basic characteristics.

The graphical representation of the linked keyword groups also helped with the initial search and selection of the keywords.
The authors considered it essential to evaluate the included results also from the perspective of citation response. Because of this criterion, four publications before 2014 were also included, which were found by examining the references in the publications obtained by

Table 3 Citation Amount of Selected Articles

\begin{tabular}{|c|c|}
\hline $\begin{array}{l}\text { Number of } \\
\text { Citations }\end{array}$ & Article \\
\hline 144 & "Determinants of costs of care for patients with Alzheimer's disease. (L. Jönsson et al, 2006)",56 \\
\hline 79 & "Net costs of dementia by disease stage: Net costs of dementia by disease stage. (Leicht et al, 20II)",57 \\
\hline 67 & $\begin{array}{l}\text { "Predictors of costs of care in Alzheimer's disease: A multinational sample of } 1222 \text { patients. (Gustavsson, Brinck, et al, } \\
20 \text { I I)" "58 }\end{array}$ \\
\hline 60 & "Activities of daily living and quality of life across different stages of dementia: a UK study. (Giebel et al, 20I5)"67 \\
\hline 29 & $\begin{array}{l}\text { "Costs of care in a mild-to-moderate Alzheimer clinical trial sample: Key resources and their determinants. (Gustavsson, } \\
\text { Cattelin, et al, 2011)",60 }\end{array}$ \\
\hline 28 & $\begin{array}{l}\text { "Cost and Care of Patients with Alzheimer's Disease: Clinical Predictors in German Health Care Settings. (Reese et al, } \\
2011) \text { " } 59\end{array}$ \\
\hline 25 & $\begin{array}{l}\text { "The Effect of Reminiscence Therapy on Cognition, Depression, and Activities of Daily Living for Patients With Alzheimer } \\
\text { Disease. (Duru Așiret \& Kapucu, 2016)"68 }\end{array}$ \\
\hline 19 & $\begin{array}{l}\text { "Economic evaluation of occupational therapy in Parkinson's disease: A randomized controlled trial: Economic Evaluation } \\
\text { OTIP Study. (Sturkenboom et al, 20I5)",80 }\end{array}$ \\
\hline 15 & "Quality of Life and Costs in Parkinson's Disease: A Cross Sectional Study in Hungary. (Tamás et al, 2014)"6l \\
\hline 11 & $\begin{array}{l}\text { "Health Care Utilisation and Cost Outcomes of a Comprehensive Dementia Care Program for Medicare Beneficiaries. } \\
\text { (Jennings et al, 2019)"51 }\end{array}$ \\
\hline 10 & $\begin{array}{l}\text { "Medical management, costs, and consequences of Alzheimer's disease in Germany: an analysis of health claims data. } \\
\text { (Brüggenjürgen et al, 2015)"62 }\end{array}$ \\
\hline 10 & $\begin{array}{l}\text { "Disease Progression in Mild Dementia due to Alzheimer Disease in an 18-Month Observational Study (GERAS): The Impact } \\
\text { on Costs and Caregiver Outcomes. (Jones et al., 2017)"63 }\end{array}$ \\
\hline 9 & $\begin{array}{l}\text { "Identifying factors of activities of daily living important for cost and caregiver outcomes in Alzheimer's disease. (Reed et al, } \\
2016) \text { ",64 }\end{array}$ \\
\hline 9 & $\begin{array}{l}\text { "Direct and Indirect Assessments of Activities of Daily Living in Behavioural Variant Frontotemporal Dementia and } \\
\text { Alzheimer Disease. (Lima-Silva et al, 2015)" } 69\end{array}$ \\
\hline 7 & "Impact of functional alterations on quality of life in patients with Alzheimer's disease. (Barbe et al, 2017)",70 \\
\hline 7 & $\begin{array}{l}\text { "Predictors of Societal Costs in Dementia Patients and Their Informal Caregivers: A Two-Year Prospective Cohort Study. } \\
\text { (Joling et al, 2015)",22 }\end{array}$ \\
\hline 5 & $\begin{array}{l}\text { "Behavioural Ratings of Executive Functioning Explain Instrumental Activities of Daily Living beyond Test Scores in } \\
\text { Parkinson's Disease. (Puente et al, 2016)",7l }\end{array}$ \\
\hline 4 & $\begin{array}{l}\text { "Taking a positive spin: preserved initiative and performance of everyday activities across mild Alzheimer's, vascular and } \\
\text { mixed dementia: Preserved everyday activities across dementia subtypes. (Giebel et al, 2017)",72 }\end{array}$ \\
\hline 4 & "Measuring activities of daily living in Parkinson's disease: On a road to nowhere and back again? (Hagell, 2019)"73 \\
\hline 2 & "Dying of amyotrophic lateral sclerosis: Health care use and cost in the last year of life. (Zwicker et al, 2019)"52 \\
\hline 2 & "Long-term medical costs of Alzheimer's disease: matched cohort analysis. (Sopina et al, 2019)"”3 \\
\hline 1 & $\begin{array}{l}\text { "Activities of Daily Living and Their Relationship to Health-Related Quality of Life in Patients with Parkinson Disease After } \\
\text { Subthalamic Nucleus Deep Brain Stimulation. (Gorecka-Mazur et al., 2019)",74 }\end{array}$ \\
\hline I & "The Real-World Medicare Costs of Alzheimer Disease: Considerations for Policy and Care. (Pyenson et al, 20|9)",54 \\
\hline 0 & "Increase in direct social care costs of Alzheimer's disease in Japan depending on dementia severity. (Takechi et al, 2019)"55 \\
\hline 0 & $\begin{array}{l}\text { "Short- and long-term cost and utilisation of health care resources in Parkinson's disease in the UK: Costs of Treating PD in } \\
\text { UK. (Weir et al, 2018)" } 65\end{array}$ \\
\hline 0 & $\begin{array}{l}\text { "Everyday functioning in Parkinson's disease: Evidence from the Revised-Observed Tasks of Daily Living (OTDL-R). (Lopez } \\
\text { et al, 2019)"75 }\end{array}$ \\
\hline 0 & $\begin{array}{l}\text { "Determinants of time to institutionalisation and related health care and societal costs in a community-based cohort of } \\
\text { patients with Alzheimer's disease dementia. (Belger et al, 2019)"66 }\end{array}$ \\
\hline
\end{tabular}


searching. Several publications fulfilled the research goal, had a high citation response, and their results were therefore considered in the analysis (Table 3).

From the articles in Table 3, four were also included in the results because they were often referred to in our selected relevant articles; these are

- Determinants of costs of care for patients with Alzheimer's disease. (L. Jönsson et al, 2006) ${ }^{56}$

- "Net costs of dementia by disease stage: Net costs of dementia by disease stage. (Leicht et al, 2011)"57

- Predictors of costs of care in Alzheimer's disease: A multinational sample of 1222 patients. (Gustavsson, Brinck, et al, 2011), 58

- "Cost and Care of Patients with Alzheimer"s Disease: Clinical Predictors in German Health Care Settings. (Reese et al, 2011), 59

\section{Results}

Finally, our systematic research included 27 studies on the basis of the extent of a patient's need for assistance in ADLs who had one or more of the four main neurodegenerative diseases in old age: AS, PDD, VaD, and ALS. The focus of the studies was divided into two main areas so that it could correspond to the specification of the goal of this study. We thus provided a comprehensive overview that identified the ADLs activities that are gradually reduced among patients with dementia, as well as explored the therapies applied in relation to dementia. This corresponds to Table 4, where the results are divided according to the four dementias. The information on the number of patients studied and the type of intervention is also provided. The authors of this review also attempted to propose recommendations for $R \& D$ that could improve the QoL of people with dementia, important for cost-saving measures. Table 5 provides up-to-date information on prices related to comprehensive and long-term care for people with dementia, namely, direct and indirect costs and their individual items, which are listed there. Therefore, for the reader to obtain information on the costs in context, the number of patients within which the data were collected and the primary purpose of the study have also been provided.

In most cases, the necessary follow-up treatment and care are related to the degree of the disease and in relation to the necessary costs; in the latter case, it is a detailed specification of ADLs or IADLs with which patients need help, and it is examined whether a specific type of therapy will help improve their QoL.

Of the 27 selected articles, seven were on PD, 13 were on $\mathrm{AD}$, and the remaining seven were combinations of various neurodegenerative diseases. Eleven studies primarily focused on costs. ${ }^{22,56-66}$ These articles focused on ADLs, iADLs, and QoL. ${ }^{61,64,67-75}$ In addition, five studies focused on one country. ${ }^{59,61,62,65,67}$ The subject sample size varied greatly across articles. In some articles, the research sample was 19 patients, and in others, the sample was 18,745 patients with different types of neurodegenerative disease. Most frequently, however, the sample was approximately a few hundred patients. The most common methods used by the authors were a questionnaire survey; a subsequent economic evaluation; and statistical data processing by correlation, chi-square, or Mann-Whitney test.

Table 5 shows the results related to costs. In many cases, the focus was the so-called societal perspective in monitoring the economic burden. In the societal perspective, the analysis considered all costs and impacts that resulted from the intervention. ${ }^{76}$ This is important for a societal perspective when making ideal decisions. ${ }^{77}$ In practice, however, the definition of the societal perspective is not so clear. In particular, it is not obvious what costs or expenses need to be involved further in the cost of health care. $^{78,79}$

For example, Leicht and Gertrud explored indirect and direct costs, whereas Gertrud classified costs that were more direct in nature- outpatient consultation, diagnostics, drugs, other health care services, non-medical costs (transport, care classified as informal) - and these were calculated by using the opportunity method or proxy method. In the calculation of indirect costs, the human capital approach method was used. €6030.2 ( $\mathrm{SD}=$ 6163.0)/patient/year was the total mean cost, whereas direct medical expenses accounted for $35.7 \%$, direct nonmedical expenses were $29.4 \%$, and indirect costs were $34.9 \%{ }^{57}$ Stated that the severity of a disease does not affect the costs of medical care. However, most of the research studies have revealed that total costs include $75 \%$ of the costs of care because care is usually performed by informal caregivers, usually family members. Thus, the care received at home becomes an additional portion of the total costs. Costs for patients living in a community were linked at the level of their impairment.

In terms of economic burden, the highest annual cost per patient was recorded in Leicht et $\mathrm{al}^{57}$ on the other hand, low 
Table 4 Summary of Selected Studies Related to Types of Therapy and Its Effectiveness for People with Dementia

\begin{tabular}{|c|c|c|c|c|}
\hline \multirow[t]{2}{*}{ Study/Authors } & \multicolumn{2}{|l|}{ Methods and Goal of the Study } & \multicolumn{2}{|c|}{ Dataset Summary and Results } \\
\hline & Used Methods & Main Goal & $\begin{array}{l}\text { Number of } \\
\text { Patients, Avg. } \\
\text { Age }\end{array}$ & Results \\
\hline \multicolumn{5}{|l|}{ Parkinson disease } \\
\hline $\begin{array}{l}\text { (Peter Hagell, } \\
2018)^{73}\end{array}$ & $\begin{array}{l}\text { "Classical test theory (CTT) } \\
\text { and Rasch measurement } \\
\text { theory (RMT)." }\end{array}$ & $\begin{array}{l}\text { "The case of a clinical PD trial } \\
\text { aiming to demonstrate ADLs } \\
\text { improvements by using the } \\
\text { ADLs section of the Unified } \\
\text { PD Rating Scale (UPDRS) to } \\
\text { measure ADLs outcomes is } \\
\text { considered" }\end{array}$ & $\begin{array}{l}675 \text { patients. Mean } \\
\text { age } 63.8 \text {. }\end{array}$ & $\begin{array}{l}\text { This work highlighted the key } \\
\text { role that health outcomes play } \\
\text { when it comes to clinical } \\
\text { studies. }\end{array}$ \\
\hline $\begin{array}{l}\text { (Agnieszka } \\
\text { Gorecka-Mazur } \\
\text { et al, 20I8) }\end{array}$ & $\begin{array}{l}\text { "HRQoL and ADLs were } \\
\text { assessed using the disease- } \\
\text { specific and generic } \\
\text { questionnaires" }\end{array}$ & $\begin{array}{l}\text { "Authors aim to investigate the } \\
\text { effects of subthalamic nucleus } \\
\text { (STN) Deep brain stimulation } \\
\text { (DBS) on HRQoL and ADLs in } \\
\text { patients with PD." }\end{array}$ & $\begin{array}{l}25 \text { patients Mean age } \\
58.0 \text {. }\end{array}$ & $\begin{array}{l}\text { "We reported significant early } \\
\text { improvements ( } 3 \text { months) in } \\
\text { the HRQoL and ADLs, and } \\
\text { these benefits increased over } \\
\text { time ( } 6 \text { months); however, } \\
\text { further improvement between } \\
6 \text { and } 12 \text { months was } \\
\text { nonsignificant. }\end{array}$ \\
\hline $\begin{array}{l}\text { (Francesca V. } \\
\text { Lopez et al, } \\
2018)^{75}\end{array}$ & $\begin{array}{l}\text { "Clinical severity of PD was } \\
\text { assessed using the H\&Y stage, } \\
\text { UPDRS, and Schwab and } \\
\text { England functional disability } \\
\text { scores" }\end{array}$ & $\begin{array}{l}\text { "Aims of the current study } \\
\text { were to examine and } \\
\text { determine the impact of } \\
\text { cognitive, motor, and mood } \\
\text { symptoms on Observed Tasks } \\
\text { of Daily Living (OTDL-R) } \\
\text { performance in PD." }\end{array}$ & $\begin{array}{l}19 \text { patients Mean age } \\
-63.5\end{array}$ & $\begin{array}{l}\text { "Patients with PD were } \\
\text { significantly slower to } \\
\text { complete the OTDL-R and } \\
\text { performed worse on only the } \\
\text { telephone use subtest, relative } \\
\text { to the HC group." }\end{array}$ \\
\hline $\begin{array}{l}\text { (Antonio Nicolas } \\
\text { Puente, 2016) }\end{array}$ & $\begin{array}{l}\text { "Comprehensive } \\
\text { neuropsychological evaluation, } \\
\text { The Lawton IADLs and Physical } \\
\text { Self-Maintenance Scales-rater } \\
\text { form, Executive functioning } \\
\text { questionnaire." }\end{array}$ & $\begin{array}{l}\text { "Authors put forward the } \\
\text { hypothesis that informant rated } \\
\text { executive functioning (EF) may } \\
\text { prove useful in providing } \\
\text { incremental validity when } \\
\text { forecasting IADLs that go } \\
\text { above and beyond EF scores." }\end{array}$ & $\begin{array}{l}\text { 120. Mean age in } \\
\text { years } 65.1\end{array}$ & $\begin{array}{l}\text { EF would add incremental } \\
\text { validity beyond tests in } \\
\text { explaining the performance of } \\
\text { IADLs in patients with PD. }\end{array}$ \\
\hline \multicolumn{5}{|l|}{ Alzheimers disease } \\
\hline $\begin{array}{l}\text { (Coralie Barbe } \\
\text { et al, 2016) }\end{array}$ & $\begin{array}{l}\text { Cross-sectional multicentre } \\
\text { study HRQoL was gauged with } \\
\text { DQoL (five domains: positive } \\
\text { affect/humour, self-esteem, } \\
\text { feeling of belonging, negative } \\
\text { affect, and sense of aesthetics) } \\
\text { MMSE }\end{array}$ & $\begin{array}{l}\text { To outline elements linked to } \\
\text { HRQoL as examined by DQoL } \\
\text { in terms of those suffering with } \\
A D \text {, with a focus on functional } \\
\text { alterations. }\end{array}$ & $\begin{array}{l}\text { 123. Mean age in } \\
\text { years } 82.0 \text {. }\end{array}$ & $\begin{array}{l}\text { "Study shows that functional } \\
\text { capacity, as measured using the } \\
\text { items of the ADLs and IADLs } \\
\text { scales, have an independent } \\
\text { impact on HRQoL in AD } \\
\text { patients." }\end{array}$ \\
\hline $\begin{array}{l}\text { (Duru Asiret G., } \\
2015)^{68}\end{array}$ & $\begin{array}{l}\text { "The Descriptive Information } \\
\text { Form, The Daily Living } \\
\text { Activities Observation Form, } \\
\text { MMSE, GDS Chi-square, } \\
\text { Mann-Whitney U-test, } \\
\text { Bonferroni tests" }\end{array}$ & $\begin{array}{l}\text { "To investigate the effect of } \\
\text { reminiscence therapy on } \\
\text { cognition, depression, activities } \\
\text { of daily living of } \\
\text { institutionalised mild and } \\
\text { moderate Alzheimer patients." }\end{array}$ & $\begin{array}{l}A D-3 I . \text { Mean age in } \\
\text { years } 81.83 \\
\text { Control } 31 \text {, age } \\
82.26\end{array}$ & $\begin{array}{l}\text { At the end of reminiscence } \\
\text { therapy sessions, an increase in } \\
\text { cognition and decrease in } \\
\text { depression were found } \\
\text { statistically significant in the } \\
\text { intervention group.' }\end{array}$ \\
\hline
\end{tabular}


Table 4 (Continued).

\begin{tabular}{|c|c|c|c|c|}
\hline \multirow[t]{2}{*}{ Study/Authors } & \multicolumn{2}{|c|}{ Methods and Goal of the Study } & \multicolumn{2}{|c|}{ Dataset Summary and Results } \\
\hline & Used Methods & Main Goal & $\begin{array}{l}\text { Number of } \\
\text { Patients, Avg. } \\
\text { Age }\end{array}$ & Results \\
\hline $\begin{array}{l}\text { (Pyenson et al, } \\
2019)^{54}\end{array}$ & $\begin{array}{l}\text { "Cost impact analysis of costs } \\
\text { for up to } 8 \text { years before the } \\
\text { year of death. Risk adjustment } \\
\text { was performed at a beneficiary } \\
\text { level using Medicare's } 2015 \\
\text { Hierarchical Condition } \\
\text { Categories." }\end{array}$ & $\begin{array}{l}\text { "To compare total Medicare- } \\
\text { covered (allowed) costs of } \\
\text { patients with Alzheimer } \\
\text { disease with the risk-adjusted } \\
\text { costs of beneficiaries without } \\
\text { dementia over their last years } \\
\text { of life, using claims data." }\end{array}$ & $\begin{array}{l}384,008 \text { Medicare } \\
\text { fee-for-service } \\
\text { beneficiaries aged } 69 \\
\text { years or older. }\end{array}$ & $\begin{array}{l}\text { In their last } 9 \text { years of life, } \\
\text { Alzheimer disease added about } \\
\text { I I\% to the average } \$ 17,000 \\
\text { per year Medicare cost for } \\
\text { same-risk beneficiaries without } \\
\text { dementia. }\end{array}$ \\
\hline \multicolumn{5}{|l|}{ Other dementia } \\
\hline $\begin{array}{l}\text { (Clarissa M. Giebel } \\
\text { et al, 2016) }\end{array}$ & $\begin{array}{l}\text { Cognitive functioning-MMSE } \\
\text { Everyday functioning - Katz } \\
\text { Index of Independence in } \\
\text { Activities of Daily Living QoL- } \\
\text { AD, NPI-Q, ChCl, CSDD }\end{array}$ & $\begin{array}{l}\text { This study aimed to examine } \\
\text { every day actions of people } \\
\text { with mild impairments, who } \\
\text { were suffering from mild forms } \\
\text { of the disease. A comparison } \\
\text { was created to see what the } \\
\text { results showed for } A D \text { and } \\
V a D \text { alongside mixed dementia. }\end{array}$ & $\begin{array}{l}\text { Total number of } \\
\text { patients with specific } \\
\text { dementia subtypes is } \\
\text { 160. Mean age in } \\
\text { years } 66.1 \text {. }\end{array}$ & $\begin{array}{l}\text { Performing activities in AD is } \\
\text { better preserved than initiating } \\
\text { activities. - Preparing a hot } \\
\text { drink and dressing and washing } \\
\text { oneself are amongst the best- } \\
\text { preserved activities across mild } \\
\text { AD, etc.' }\end{array}$ \\
\hline $\begin{array}{l}\text { (Thais Bento Lima- } \\
\text { Silva et al,2014) }\end{array}$ & $\begin{array}{l}\text { "Direct Assessment of } \\
\text { Functional Performance } \\
\text { (DAFS-BR) and usual cognitive } \\
\text { measures (MMSE, Clinical } \\
\text { Dementia Rating (CDR) } \\
\text { scores. The Disability } \\
\text { Assessment for Dementia was } \\
\text { completed by caregivers." }\end{array}$ & $\begin{array}{l}\text { To compare direct and indirect } \\
\text { assessments of activities of } \\
\text { daily living (ADLs) in } \\
\text { behavioural variant } \\
\text { frontotemporal dementia } \\
\text { (bvFTD) and AD and their } \\
\text { relationship with cognitive } \\
\text { performance. }\end{array}$ & $\begin{array}{l}\text { A total of } 84 \\
\text { individuals, aged } 55 \\
\text { or older; AD } 30 \text {, age } \\
68.7 ; \text { FTD } 20 \text {, age } \\
67.05 \text {; control } 34 \text {, } \\
\text { age } 65.4 \text { I }\end{array}$ & $\begin{array}{l}\text { Results suggested higher } \\
\text { cognitive impairment among } \\
\text { patients with AD yet higher } \\
\text { functional impairment among } \\
\text { patients with bvFTD.' }\end{array}$ \\
\hline $\begin{array}{l}\text { (Clarissa M. Giebel } \\
\text { et al, 2014) }\end{array}$ & $\begin{array}{l}\text { Measures of cognition and QoL } \\
\text { (MMSE, Katz Index of } \\
\text { Independence in Activities of } \\
\text { Daily Living, NPI-Q, (QoL-AD) } \\
\text { rating scale) Using frequency, } \\
\text { correlation and multiple } \\
\text { regression analysis }\end{array}$ & $\begin{array}{l}\text { The aim was to identify the } \\
\text { tasks which were impossible to } \\
\text { perform in each phase of } \\
\text { dementia and detect their } \\
\text { impact on a patient's QoL. }\end{array}$ & $\begin{array}{l}\text { AD I09 VD2I Mix } \\
\text { 30. Mean age } 83.7\end{array}$ & $\begin{array}{l}\text { Explicit knowledge of daily } \\
\text { functioning across mild, } \\
\text { moderate, and severe dementia } \\
\text { can guide daily activity } \\
\text { interventions to address any } \\
\text { impairment in the appropriate } \\
\text { activity as early as possible.' }\end{array}$ \\
\hline
\end{tabular}

in. ${ }^{65}$ These results differed in the purpose of the study and thus the inclusion of cost groups. Other factors were the price level of the country or the method of the calculation of indirect costs. There has been a consensus that a high proportion of costs are incurred by non-formal care. There have also been significant differences in calculations, due to the expression of costs through lost wages. In monitoring the cost of patients in relation to the types of dementia, the results show no significant differences, that is, in the results of cost range margins $^{22,56,57,60-62,65}$ can be compared or the differences in the selected variables studied in the detected studies that examined multiple types of dementia and compared values. $^{22,62,69,72}$

For the aforementioned costs, there is a division into formal and informal care, which often overlaps with an approach of direct and indirect costs. In any case, a group of medical costs where medications, hospitalisations and outpatient visits belong forms a smaller share of the whole. Social care (such as community care services, structural adaptations) accounts for a larger share of direct costs. In informal care, costs are often calculated using what the family member loses by spending time on the patient. The 
Table 5 Summary of Selected Studies in Relation to Monitoring the Economic Burden in the Context of Chosen Dementia

\begin{tabular}{|c|c|c|c|c|c|c|}
\hline \multirow{2}{*}{$\begin{array}{l}\text { Studyl } \\
\text { Authors }\end{array}$} & \multicolumn{2}{|l|}{ Mentioned Costs } & \multicolumn{2}{|c|}{ Methods and Goal of the Study } & \multicolumn{2}{|c|}{ Dataset Summary and Results } \\
\hline & Direct & Indirect & Used Methods & Main Goal & $\begin{array}{l}\text { Number } \\
\text { of } \\
\text { Patients, } \\
\text { Avg. Age }\end{array}$ & Results \\
\hline \multicolumn{7}{|c|}{ Parkinson disease } \\
\hline $\begin{array}{l}\text { (Gertrúd } \\
\text { Tamás et al, } \\
20 \mid 4)^{61}\end{array}$ & $\begin{array}{l}\text { Outpatient } \\
\text { consultation, } \\
\text { diagnostics, drugs, } \\
\text { other health care } \\
\text { services, non- } \\
\text { medical costs } \\
\text { (transport, informal } \\
\text { care) }\end{array}$ & Productivity loss & $\begin{array}{l}\text { Cross-sectional } \\
\text { survey cost } \\
\text { calculation- } \\
\text { societal perspective }\end{array}$ & $\begin{array}{l}\text { Aim was to evaluate QoL } \\
\text { alongside the expenses } \\
\text { related to PD in Hungary } \\
\text { to examine the links } \\
\text { between the two. }\end{array}$ & $\begin{array}{l}110- \\
\text { patients } \\
63.3- \\
\text { mean age }\end{array}$ & $\begin{array}{l}\text { COST (I year) } 6030 \\
\text { EUR/patient }\end{array}$ \\
\hline $\begin{array}{l}\text { (Weir Sharada } \\
\text { et al, 2018) }\end{array}$ & $\begin{array}{l}\text { Inpatient, outpatient } \\
\text { hospital, accidents } \\
\text { and emergency } \\
\text { primary care, } \\
\text { medication }\end{array}$ & NA & $\begin{array}{l}\text { Retrospective } \\
\text { population-based } \\
\text { cohort study using } \\
\text { linked data from } \\
\text { the UK Clinical } \\
\text { Practice Research } \\
\text { Datalink and } \\
\text { Hospital Episode } \\
\text { Statistics } \\
\text { databases.' }\end{array}$ & $\begin{array}{l}\text { This work outlined } \\
\text { proper estimates of the } \\
\text { costs attached to the care } \\
\text { of patients with PD, as per } \\
\text { the data collected on a } \\
\text { routine basis. }\end{array}$ & $\begin{array}{l}7060- \\
\text { patients } \\
72.6- \\
\text { mean age }\end{array}$ & $\begin{array}{l}\text { Mean cost of health } \\
\text { care for such patients } \\
\text { was approximately } \\
£ 5022 \text { annually. }\end{array}$ \\
\hline $\begin{array}{l}\text { (Sturkenboom } \\
\text { H. W. M. Ingrid } \\
\text { et al, 20I5) }\end{array}$ & $\begin{array}{l}\text { Healthcare consults } \\
\text { and medication, } \\
\text { institutional care, } \\
\text { aids and } \\
\text { adaptations. }\end{array}$ & $\begin{array}{l}\text { Informal care } \\
\text { (home care, } \\
\text { absence work) }\end{array}$ & $\begin{array}{l}\text { Quality-adjusted } \\
\text { life-year (QALY), } \\
\text { net monetary } \\
\text { benefit (NMB) } \\
\text { statistic proved } \\
\text { useful in analysing } \\
\text { cost-efficacy. }\end{array}$ & $\begin{array}{l}\text { "Home-based } \\
\text { occupational therapy } \\
\text { improves perceived } \\
\text { performance in daily } \\
\text { activities of people with } \\
\text { (PD). The aim of the } \\
\text { current study was to } \\
\text { evaluate the cost- } \\
\text { effectiveness of this } \\
\text { intervention." }\end{array}$ & $\begin{array}{l}124- \\
\text { patients } \\
71.0- \\
\text { average } \\
\text { age }\end{array}$ & $\begin{array}{l}\text { "Group differences in } \\
\text { costs and health utilities } \\
\text { I } 302 \text { euro (mean) The } \\
\text { mean net monetary } \\
\text { benefit of the } \\
\text { intervention at a WTP } \\
\text { value of EUR40,000." }\end{array}$ \\
\hline \multicolumn{7}{|c|}{ Alzheimers disease } \\
\hline $\begin{array}{l}\text { Jones W. Roy } \\
\text { et al, 2017) }\end{array}$ & $\begin{array}{l}\text { Direct medical } \\
\text { costs }\end{array}$ & $\begin{array}{l}\text { Informal care - } \\
\text { opportunity cost } \\
\text { approach }\end{array}$ & $\begin{array}{l}\text { Cognitive function - } \\
\text { MMSE, ADCS- } \\
\text { ADLs score, Zarit } \\
\text { Burden Interview } \\
\text { (ZBI), cost - } \\
\text { Utilisation in } \\
\text { Dementia (RUD) } \\
\text { instrument }\end{array}$ & $\begin{array}{l}\text { Aim was to evaluate } \\
\text { whether the decrease in } \\
\text { cognitive and functionality } \\
\text { was observed in } \\
\text { community-dwelling } \\
\text { patients suffering from } \\
\text { mild AD and was } \\
\text { connected with higher } \\
\text { societal costs and } \\
\text { caregiver burden and time } \\
\text { results. }\end{array}$ & $\begin{array}{l}494- \\
\text { patients } \\
77.1 \text { - } \\
\text { mean age }\end{array}$ & $\begin{array}{l}\text { "Mean monthly cost of } \\
€ I, 400 \text { to } € 2,254 \text { in } \\
\text { patients with functional } \\
\text { decline and } € I, 778 \text { in } \\
\text { those with cognitive } \\
\text { decline." }\end{array}$ \\
\hline
\end{tabular}

(Continued) 
Table 5 (Continued).

\begin{tabular}{|c|c|c|c|c|c|c|}
\hline \multirow{2}{*}{$\begin{array}{l}\text { Studyl } \\
\text { Authors }\end{array}$} & \multicolumn{2}{|l|}{ Mentioned Costs } & \multicolumn{2}{|c|}{ Methods and Goal of the Study } & \multicolumn{2}{|c|}{ Dataset Summary and Results } \\
\hline & Direct & Indirect & Used Methods & Main Goal & $\begin{array}{l}\text { Number } \\
\text { of } \\
\text { Patients, } \\
\text { Avg. Age }\end{array}$ & Results \\
\hline $\begin{array}{l}\text { (Catherine } \\
\text { Reed et al, } \\
2015)^{64}\end{array}$ & $\begin{array}{l}\text { Patient health care } \\
\text { and social care } \\
\text { costs, }\end{array}$ & Caregiver time & $\begin{array}{l}\text { Study of } \\
\text { community-living } \\
\text { AD patients } \\
\text { (GERAS) MMSE, } \\
\text { BADLs, IADLs, } \\
\text { Cost - opportunity } \\
\text { cost approach }\end{array}$ & $\begin{array}{l}\text { Authors attempted to } \\
\text { find a more } \\
\text { comprehensive picture } \\
\text { and take on different } \\
\text { facets of how a patient } \\
\text { functions and how this } \\
\text { impacts the caregiver } \\
\text { outcomes and costs for } \\
\text { those with AD. }\end{array}$ & $\begin{array}{l}\text { I497 - } \\
\text { patients } \\
77.6 \text { - age }\end{array}$ & $\begin{array}{l}\text { Total societal costs for } \\
\text { mild is } € \mid 325 \text {, for } \\
\text { moderate } € \mid 884 \text { and } \\
\text { for severe } € 2908 \text {. }\end{array}$ \\
\hline $\begin{array}{l}\text { Jens Peter } \\
\text { Reese et al, } \\
2011)^{59}\end{array}$ & $\begin{array}{l}\text { Hospital, outpatient } \\
\text { treatment, ancillary } \\
\text { therapy, special } \\
\text { equipment, care, } \\
\text { antidementia, total } \\
\text { drugs }\end{array}$ & $\begin{array}{l}\text { Indirect costs: a) } \\
\text { retiring early, b) } \\
\text { lack of ability to } \\
\text { work, c) no } \\
\text { employment, d) } \\
\text { sick leave and e) a } \\
\text { fall in labour time } \\
\text { caused by AD }\end{array}$ & $\begin{array}{l}\text { MMSE, NPI, GDS, } \\
\text { structured } \\
\text { questionnaire, } \mathrm{QaL} \\
\mathrm{AD}\end{array}$ & $\begin{array}{l}\text { "The study aims to report } \\
\text { service use and costs for } \\
\text { patients with Alzheimer's } \\
\text { disease (AD) and to } \\
\text { explore the incremental } \\
\text { influence of } \\
\text { sociodemographic and } \\
\text { illness-related } \\
\text { determinants in } \\
\text { ambulatory and inpatient } \\
\text { settings". }\end{array}$ & $\begin{array}{l}395- \\
\text { patients } \\
80.2- \\
\text { mean age. }\end{array}$ & $\begin{array}{l}\text { Annual cost D25,500 } \\
\text { for those in long-term } \\
\text { care facilities and over } \\
\text { D7,450 for those at } \\
\text { home (EUR) }\end{array}$ \\
\hline $\begin{array}{l}\text { (Leicht } \mathrm{H} \text {. } \\
\text { et al, 20II) }\end{array}$ & $\begin{array}{l}\text { Inpatient treatment, } \\
\text { medical supplies and } \\
\text { dental prostheses, } \\
\text { outpatient physician } \\
\text { treatment, } \\
\text { pharmaceuticals, } \\
\text { nursing home care }\end{array}$ & $\begin{array}{l}\text { Informal care } \\
\text { (Care and } \\
\text { assistance provided } \\
\text { by family or } \\
\text { friends,) }\end{array}$ & $\begin{array}{l}\text { In a cross-sectional } \\
\text { study, costs of } \\
\text { illness. }\end{array}$ & $\begin{array}{l}\text { "To estimate net costs of } \\
\text { dementia by degree of } \\
\text { severity from a societal } \\
\text { perspective." }\end{array}$ & $\begin{array}{l}176- \\
\text { patients } \\
85.3 \text { - age }\end{array}$ & $\begin{array}{l}\text { "Annual net costs of } \\
\text { dementia by stage were } \\
\text { approximately } € 15,000 \\
\text { (mild), } € 32,000 \\
\text { (moderate) and } € 42,000 \\
\text { (severe)" }\end{array}$ \\
\hline $\begin{array}{l}\text { (Linus Jonsson } \\
\text { et al, 2006) }\end{array}$ & $\begin{array}{l}\text { Medical care costs } \\
\text { (inpatient care, } \\
\text { outpatient care, } \\
\text { pharmaceuticals) }\end{array}$ & $\begin{array}{l}\text { Informal care (Lost } \\
\text { production, lost } \\
\text { leisure time) }\end{array}$ & $\begin{array}{l}\text { Questionnaires, } \\
\text { MMSE, NPI, } \\
\text { opportunity cost } \\
\text { methods }\end{array}$ & $\begin{array}{l}\text { "This study aims to } \\
\text { estimate the costs of } \\
\text { formal and informal care } \\
\text { and identity determinants } \\
\text { of care costs." }\end{array}$ & $\begin{array}{l}272- \\
\text { patients } \\
75.9- \\
\text { average } \\
\text { age }\end{array}$ & $\begin{array}{l}\text { "annual costs were on } \\
\text { average SEKI } 72000\end{array}$ \\
\hline $\begin{array}{l}\text { (Gustavsson } \\
\text { Anders et al, } \\
201 \mathrm{I})^{58}\end{array}$ & $\begin{array}{l}\text { Accommodation, } \\
\text { hospitalisation, } \\
\text { community care } \\
\text { services }\end{array}$ & $\begin{array}{l}\text { Informal care (Lost } \\
\text { production, lost } \\
\text { leisure time) }\end{array}$ & $\begin{array}{l}\text { Interviews disease } \\
\text { severity measures - } \\
\text { MMSE, ADLs, NPI }\end{array}$ & $\begin{array}{l}\text { "Authors aimed to } \\
\text { identify what measures of } \\
\text { disease severity are the } \\
\text { most important } \\
\text { predictors of societal } \\
\text { costs of care and whether } \\
\text { their relationship differs } \\
\text { across countries." }\end{array}$ & $\begin{array}{l}1222- \\
\text { patients } \\
78-\text { mean } \\
\text { age }\end{array}$ & $\begin{array}{l}\text { "Community dwelling } \\
\text { (severe USA:1837;Spain } \\
\text { I53I; mild USAI204) } \\
\text { Residential care (USA, } \\
\text { severe: 5I|4;Swede } \\
\text { 3698liber)" }\end{array}$ \\
\hline
\end{tabular}

(Continued) 
Table 5 (Continued).

\begin{tabular}{|c|c|c|c|c|c|c|}
\hline \multirow{2}{*}{$\begin{array}{l}\text { Studyl } \\
\text { Authors }\end{array}$} & \multicolumn{2}{|l|}{ Mentioned Costs } & \multicolumn{2}{|c|}{ Methods and Goal of the Study } & \multicolumn{2}{|c|}{ Dataset Summary and Results } \\
\hline & Direct & Indirect & Used Methods & Main Goal & $\begin{array}{l}\text { Number } \\
\text { of } \\
\text { Patients, } \\
\text { Avg. Age }\end{array}$ & Results \\
\hline $\begin{array}{l}\text { (Gustavsson } \\
\text { A., 2011) }\end{array}$ & $\begin{array}{l}\text { Accommodation, } \\
\text { hospitalisation, } \\
\text { emergency care, } \\
\text { outpatient care, } \\
\text { medication, } \\
\text { community care } \\
\text { services }\end{array}$ & $\begin{array}{l}\text { Informal care (Lost } \\
\text { production, lost } \\
\text { leisure time) }\end{array}$ & $\begin{array}{l}\text { Costs of care - } \\
\text { RUD Disease } \\
\text { severity measures } \\
\text { (MMSE, ADLs, } \\
\text { Neuropsychiatric } \\
\text { Inventory } \\
\text { Questionnaire) }\end{array}$ & $\begin{array}{l}\text { "To identify (a) the key } \\
\text { resource items in a } \\
\text { clinical trial setting and (b) } \\
\text { how are they correlated } \\
\text { with one another and } \\
\text { with measures of disease } \\
\text { severity." }\end{array}$ & $\begin{array}{l}1378- \\
\text { patients } \\
75.0- \\
\text { average } \\
\text { age }\end{array}$ & $\begin{array}{l}\text { "The annual costs } \\
£ 9,308(10,924 ; \\
\$ 13,353) \text { in mild, } \\
€ \mid 3,980(16,408 ; \\
\$ 20,055) \text { in moderate } \\
€ 19,957(23,422 ; \\
\$ 28,629) \text { in severe." }\end{array}$ \\
\hline $\begin{array}{l}\text { (Mark Belger } \\
\text { et al, 2018) }\end{array}$ & $\begin{array}{l}\text { "Patient health care } \\
\text { (medications, } \\
\text { hospitalisations and } \\
\text { outpatient visits) } \\
\text { social care } \\
\text { (community care } \\
\text { services, } \\
\text { structural } \\
\text { adaptations)" }\end{array}$ & $\begin{array}{l}\text { Informal care (time } \\
\text { spent giving care } \\
\text { and missing work) }\end{array}$ & $\begin{array}{l}\text { GERAS study } \\
\text { design, MMSE, } \\
\text { ADCS-ADLs and } \\
\text { NPI, Opportunity } \\
\text { cost approach }\end{array}$ & $\begin{array}{l}\text { "To examine the costs of } \\
\text { caring for community- } \\
\text { dwelling patients with AD } \\
\text { dementia in relation to } \\
\text { the time to } \\
\text { institutionalisation." }\end{array}$ & $\begin{array}{l}1495- \\
\text { patients } \\
77.6- \\
\text { average } \\
\text { age }\end{array}$ & $\begin{array}{l}\text { "In the five years pre- } \\
\text { institutionalisation, } \\
\text { monthly total societal } \\
\text { costs increased by more } \\
\text { than } € 1000 \text { ( } € \mid 166 \\
\text { equivalent for } 2010 \text { ) } \\
\text { from } € \mid 900 \text { to } € 3160 \\
\text { and monthly total } \\
\text { patient costs almost } \\
\text { doubled from } € 770 \text { to } \\
€ \mid 529 \text {." }\end{array}$ \\
\hline $\begin{array}{l}\text { (Hajime } \\
\text { Takechi et al, } \\
2019)^{55}\end{array}$ & $\begin{array}{l}\text { Medical care, social } \\
\text { care, visiting } \\
\text { rehabilitation, day } \\
\text { services }\end{array}$ & $\begin{array}{l}\text { Informal care (time } \\
\text { spent giving care } \\
\text { and missing work) }\end{array}$ & $\begin{array}{l}\text { This study involved } \\
169 \text { people with } A D \\
\text { or } \mathrm{MCl} \text { and who } \\
\text { were observed for a } \\
\text { certain period of } \\
\text { time. }\end{array}$ & $\begin{array}{l}\text { "The aim was to assess } \\
\text { the cost of direct social } \\
\text { support for } A D \text { under } \\
\text { long-term care insurance } \\
\text { in Japan." }\end{array}$ & $\begin{array}{l}169 \\
\text { patients - } \\
81.3 \\
\text { average } \\
\text { age }\end{array}$ & $\begin{array}{l}\text { "Direct social support } \\
\text { and costs rose } \\
\text { considerably between } \\
\text { people in all stages of } \\
\text { dementia }(P<0.001) \text {." }\end{array}$ \\
\hline $\begin{array}{l}\text { (Elizaveta } \\
\text { Sopina et al, } \\
2019)^{53}\end{array}$ & $\begin{array}{l}\text { Medical costs, } \\
\text { hospital costs. }\end{array}$ & $\begin{array}{l}\text { Informal care (Lost } \\
\text { production, lost } \\
\text { leisure time) }\end{array}$ & $\begin{array}{l}\text { "Multiple logistic } \\
\text { regressions to } \\
\text { generate } \\
\text { propensity scores } \\
\text { to match } 26,95 \text { I } \\
\text { incident cases of } \\
\text { AD with } 26,95 \text { I } \\
\text { people without } \\
\text { AD." }\end{array}$ & $\begin{array}{l}\text { "Medical costs connected } \\
\text { with } A D \text { are uncertain and } \\
\text { often presented in a format } \\
\text { inadequate for decision } \\
\text { modelling. The authors } \\
\text { tried to estimate long-term } \\
\text { medical costs associated } \\
\text { with } A D \text { and compared to } \\
\text { the general population for } \\
\text { use in decision modelling." }\end{array}$ & $\begin{array}{l}26,951 \\
\text { patients - } \\
80.4 \\
\text { average } \\
\text { age }\end{array}$ & $\begin{array}{l}\text { "AD was connected with } \\
\text { considerably higher costs, } \\
\text { driven by medication and } \\
\text { hospital costs, particularly } \\
\text { at the time of diagnosis. } \\
\text { Mean total medical cost } \\
\text { was } € 4996 \text { higher for AD } \\
\text { than for the control group } \\
\text { in the year of diagnosis." }\end{array}$ \\
\hline \multicolumn{7}{|l|}{ Other dementia } \\
\hline $\begin{array}{l}\text { (Bernd } \\
\text { Brüggenjürgen } \\
\text { et al, 2015) }\end{array}$ & $\begin{array}{l}\text { Number of } \\
\text { hospitalisations, } \\
\text { number of inpatient } \\
\text { days, number of } \\
\text { ambulatory physician } \\
\text { visits, number of } \\
\text { drugs used }\end{array}$ & $\begin{array}{l}\text { Informal care } \\
\text { (productivity loss } \\
\text { of caregivers) }\end{array}$ & $\begin{array}{l}\text { Cross-sectional } \\
\text { analyses direct } \\
\text { costs from the SHI } \\
\text { payer perspective }\end{array}$ & $\begin{array}{l}\text { "To assess the medical } \\
\text { and economic differences } \\
\text { between patients with } \\
\text { and without diagnosed } \\
\text { AD, VD)" }\end{array}$ & $\begin{array}{l}18,745- \\
\text { patients } \\
79.8- \\
\text { mean age }\end{array}$ & $\begin{array}{l}\text { COST(I year) AD: } \\
74 \mid 3-9207 \text { controls: } \\
€ 3,378-3,850\end{array}$ \\
\hline
\end{tabular}

(Continued) 
Table 5 (Continued).

\begin{tabular}{|c|c|c|c|c|c|c|}
\hline \multirow{2}{*}{$\begin{array}{l}\text { Studyl } \\
\text { Authors }\end{array}$} & \multicolumn{2}{|l|}{ Mentioned Costs } & \multicolumn{2}{|c|}{ Methods and Goal of the Study } & \multicolumn{2}{|c|}{ Dataset Summary and Results } \\
\hline & Direct & Indirect & Used Methods & Main Goal & $\begin{array}{l}\text { Number } \\
\text { of } \\
\text { Patients, } \\
\text { Avg. Age }\end{array}$ & Results \\
\hline $\begin{array}{l}\text { (Karlijn J. Joling } \\
\text { et al, 20I5) }\end{array}$ & $\begin{array}{l}\text { "Ambulatory care } \\
\text { day treatment and } \\
\text { admissions } \\
\text { medication" }\end{array}$ & $\begin{array}{l}\text { "Home care and } \\
\text { other support, } \\
\text { Absenteeism, } \\
\text { Intervention - } \\
\text { Costs of the family } \\
\text { meetings } \\
\text { intervention } \\
\text { including two } \\
\text { individual and four } \\
\text { family counselling } \\
\text { sessions, and ad } \\
\text { hoc counselling)" }\end{array}$ & $\begin{array}{l}\text { "Interviews, Family } \\
\text { Meetings (FAME) } \\
\text { study, cost)- } \\
\text { effectiveness of a } \\
\text { family meeting } \\
\text { intervention" }\end{array}$ & $\begin{array}{l}\text { "This study aimed to } \\
\text { identify predictors of the } \\
\text { total societal costs in AD } \\
\text { and dementia mixed } \\
\text { patients and their } \\
\text { informal caregivers." }\end{array}$ & $\begin{array}{l}192- \\
\text { patients, } \\
74.7 \\
\text { average } \\
\text { age }\end{array}$ & $\begin{array}{l}\text { "Societal costs } 71,514 \\
\text { per person in year } \\
\text { (informal care 59\%)" }\end{array}$ \\
\hline $\begin{array}{l}\text { (Zwicker et al, } \\
2019)^{52}\end{array}$ & $\begin{array}{l}\text { Drug costs and } \\
\text { physician fees }\end{array}$ & Loss of income & $\begin{array}{l}\text { "Retrospective, } \\
\text { population-based } \\
\text { cohort study of } \\
\text { Ontario, Canada } \\
\text { (2013-2015)." }\end{array}$ & $\begin{array}{l}\text { "To explore the } \\
\text { exploitation of health care } \\
\text { service and costs for dead } \\
\text { people with and without } \\
\text { ALS in the last year of } \\
\text { life." }\end{array}$ & $\begin{array}{l}1212 \\
\text { patients. } \\
70 \text { average } \\
\text { age. }\end{array}$ & $\begin{array}{l}\text { "Average cost of care in } \\
\text { the last year of life was } \\
\text { higher for those with } \\
\text { ALS }(\$ 68,3 \text { I I.98 vs } \\
\$ 55,773.48 \text {, p }<0.00 \text { I)." }\end{array}$ \\
\hline $\begin{array}{l}\text { (Jennings et al, } \\
2019)^{51}\end{array}$ & $\begin{array}{l}\text { Hospitalisations, } \\
\text { visits, drugs }\end{array}$ & $\begin{array}{l}\text { Informal care } \\
\text { (productivity loss } \\
\text { of caregivers) }\end{array}$ & $\begin{array}{l}\text { Quasiexperimental } \\
\text { study to juxtapose } \\
\text { the exploitation of } \\
\text { health care and } \\
\text { costs for } 1083 \\
\text { Medicare } \\
\text { individuals. }\end{array}$ & $\begin{array}{l}\text { "To assess the } \\
\text { exploitation of health care } \\
\text { and cost results of a } \\
\text { complex dementia care } \\
\text { plan for Medicare } \\
\text { individuals." }\end{array}$ & $\begin{array}{l}1083 \\
\text { patients. } \\
82.1 \\
\text { average } \\
\text { age. }\end{array}$ & $\begin{array}{l}\text { "The total cost of care } \\
\text { to Medicare, excluding } \\
\text { programme costs, was } \\
\$ 60 \text { I less per patient } \\
\text { per quarter }(95 \% \mathrm{Cl},- \\
\$ 1198 \text { to }-\$ 5) \text {." }\end{array}$ \\
\hline
\end{tabular}

main indirect cost losses include lost productivity, absenteeism, the need for part-time work, and the creation of savings. $57,59,61,62,64,71,74,75,80$ The authors agree that the more severe the patient's condition, the cost of treatment and care increases exponentially, and any additional activity that the patient is unable to perform alone. ${ }^{58,64,65,71}$ For instance, for AD's disease, the total social cost is on average 1,984 euros. For the mild phase, $€ 1.355$, for the moderate severity, $€ 1.884$ per month, and for the severe phase, $€ 2.908$ per month. ${ }^{64}$

Notably, the information on the amount of care costs, what activities patients require, and how high the level of high care are also important. Another part of the studies examined (Table 4) points out the specific activities/tasks that people with dementia need to cope with. Out of the total number of results found, nine studies focus on these tasks and on whether a certain type of therapy will positively influence patients' independence. Agnieszka
Gorecka showed that DBS or deep brain stimulation, when applied to the STN (subthalamic nucleus) could result in a decrease of motor issues for those suffering from PD, and can further augment their HRQoL. In addition, their findings indicate that their patients considerably improved after three months ADLs and HRQoL, and with time these benefits only grew.

Clarissa et $\mathrm{al}^{72}$ investigated which tasks are affected at each phase of dementia and how much this is linked with differences in QoL across the various phases of this disease. They found out that toileting, transfer, and feeding are not affected in the moderate stage of dementia. It might be argued that activities, for example, feeding, depend mainly on physical feedback. Although physical feelings might work as a cue for conducting every ADLs, bathing, dressing, and continence worsen in the initial phases of dementia. Thus, the extent to which ADLs depend on physical feedback can differ. The authors also confirm 
that cognitive functioning is not connected with PwDbased QoL ratings.

Barbe et $\mathrm{al}^{70}$ revealed that functional scope, as assessed by the IADLs and ADLs scales, independently affects HRQoL among people with AD. For instance, enhanced HRQoL was associated with patients' being able to move around on their own or being able to telephone. By contrast, meal delivery was associated negatively with HRQoL. Nevertheless, meal delivery also caused a positive impact on the HRQoL of the patients in question, especially in terms of the social area substituting their feelings of loneliness. The authors also confirmed that patients who could not go shopping, travel, or perform treatment for themselves on their own, had no experience of a negative impact when it came to their HRQoL. The variations commonly found in older subjects do not hold the same level of stigma when looking at people with AD.

The main findings in relation to certain therapies and patient groups are provided in Table 4 .

The results show that the performance of individual ADLs worsens differently in each stage of dementia, which is significant knowledge for enhancing patient's QoL in each phase of disease. ${ }^{67}$ Regarding the activities that require the aforementioned high cost of care, there is a clear need for assistance in the following areas: eating, drinking, dressing, bathing, personal hygiene, toilet, and transport (Table 4). Among the activities that patients can manage relatively alone, or have not been investigated in the detected studies, are taking medications and bed and chair movements.

\section{Discussion}

In the context of the first aim of this review, that is, identification of ADLs activities that are gradually reduced among patients with dementias, the obtained results show that essential assistance occurs in connection with the following activities, which can be characterised by the most important ones in ADLs in the dementias context: eating and drinking (70\%), dressing (48\%), bathing and personal hygiene (59\%), use of toilet (51\%), and transport (74\%). By contrast, shopping or cleaning are not addressed as much. Primarily, this is influenced by the focus of the research, which includes people with higher degrees of dementia, where this issue is almost no longer relevant. This act is automatically associated with visits and staff.

Regarding the effectiveness of therapies applied in relation to dementia and in what how they are effective in attempting to improve QoL, we conclude that this area of research requires further investigations to make a meaningful-not misleading-conclusions. This is a consequence of QoL being a multidimensional and complex construct of various impacts and interplays (Section 2).

In terms of the second aim of the paper, that is, examination of costs related to treatment and caregiving, The obtained results show that the research covers both direct (e.g. medical and hospital costs, treatment, accommodations) and indirect costs (e.g. loss of production or leisure time, home care, loss of income). The highest costs are the informal costs, calculating the lost salary of the informal caregiver, based on the time burden, which is often 24 hours a day. Even in a situation where one addresses the senior, that is, these items are not quantified, research has proved that care undesirably affects the QoL and health and thus indirectly augments health costs again.

Although the research findings concerning the costs of care which is informal in nature can vary across the countries, on average, these costs are one third of total costs. They are higher, for example, in the United States than in Western Europe. By contrast, Western Europe has higher costs in comparison with central European countries, such as Hungary. For instance, a Swedish study by ${ }^{60}$ estimated the costs of informal care between $30 \%$ and $60 \%$. A Danish study by ${ }^{22}$ reported that $60 \%$ of costs is attributed to the cost of informal care, and study by ${ }^{69}$ showed that informal care's costs contributed to $43 \%$ of direct costs. Furthermore, a study by ${ }^{60}$ claimed that ADLs are the key forecasters of societal costs and therefore should be a key aspect in the economic evaluation of the given therapies. Notably, these therapies (e.g. occupational therapy, reminiscence therapy, or deep brain stimulation) seem to have a beneficial effect on the performance of ADLs. ${ }^{68,74,80}$ Deep brain stimulation therapy appeared to have an additional effect on emotional well-being, social support, and cognition, ${ }^{74}$ and the reminiscence therapy had an important positive impact on communication, socialisation, and restlessness, ${ }^{68}$ a factor also crucial for general well-being. Moreover, the therapies should focus on initiative of activities, not only on their performance. It is important to maintain ADLs abilities because they help delay long-term institutionalised care, which is very costly. Another factor that plays a significant role in institutionalisation is the caregiver factor. That is, having a spouse caregiver can delay a patient's institutionalisation by at least 2.5 years. $^{66}$ As the findings of a German study ${ }^{59}$ reveal, the annual costs in total were on average $€ 25,500$ for individuals residing in longer-term care institutes and 
$€ 7,450$ for those at home. Generally, dementia is an expensive neurological disorder. Leicht et $\mathrm{al}^{57}$ explained that net costs usually become twice what they should be when the state goes from mild to severe, because of the increasing dependence on nursing care. Therefore, as Jones et $\mathrm{al}^{63}$ reported, if the increase in costs and caregiver outcomes prove to be causally associated with disease progression as it was in their study, intervention therapies will be of high importance and cost-effective for individuals in the mild stage. Similar findings were also confirmed by Joling, ${ }^{22}$ who reported that the therapies especially targeted at the reduction of patients' IADLs and ADLs dependencies may basically lead to useful socioeconomic benefits. Moreover, Reed et $\mathrm{al}^{64}$ identified four distinct ADLs subdomains which have an important impact on costs and caregiver outcomes in AD. These include basic activities (washing, getting dressed, or making tea or coffee), basic household chores, communicating, and outdoor activities. Thus, a lower ability to take care of oneself is connected with poor patient health and higher costs of social care because the patient requires care that can only be provided by external sources, such as house-helpers or nurses who visit the patient.

Thus, to optimise the costs of the overall costs of neurological disorders, such as AD or PD, attention should be paid to the relevant therapies with a proven positive impact on both the initiative and performance of ADLs in individuals presenting with mild and moderate stages of dementias. In addition, people with dementia should be provided with a tailored-made personal programme for care, which should be based on objective evaluations of all the functional factors influencing them. ${ }^{70}$

Furthermore, one holistic solution that may contribute to a decline in care costs, as well as to the improvement of QoL of older adults with dementias and their caregivers, be it nurses or family members, is the solution based on technology, as proposed by Baraković et al. ${ }^{9}$ Indisputably, those technology solutions must be developed in cooperation with the ultimate users to satisfy their needs because putting the products on the marketplace without being validated by the users is not a meaningful utilisation of the R\&D community. It is necessary to develop standards for older generation groups to improve their QoL. Furthermore, it is necessary to validate and verify approaches to demonstrate the consistency and long-term scope of all such health-related technology solutions.

Other challenges that must often be overcome in this context are the legislative barriers, reluctance of people to use technology, or insufficient adaptation of solutions to the needs and abilities of seniors. Ambient Assistive Living technologies ${ }^{81}$ and Smart Home systems ${ }^{82}$ are considered beneficial technologies that aid people suffering from the illness and their caregivers. Control is conducted by passive and active IR motion sensors, ${ }^{83}$ which seems to be an appropriate solution to extend the time of independent living among older people. New approaches involving machine learning generated favourable outcomes. ${ }^{84}$

At this point, how and where the presence of a person is irreplaceable needs to be determined; if such things are identified, these solutions might in part of completely reduce the duties of caregivers. All this should be solved to address augmenting QoL for patients and their caregivers. As aforementioned, ADLs ability, especially in basic areas such as getting dressed or washing, is the main predictor of societal costs of care, ${ }^{60}$ out of which informal care represents the largest share of total societal costs in terms of those with mild to moderate levels of disease. ${ }^{58,85}$ This approach also coincides with that provided by Maresova et al, in terms of the need to consider different aspects of well-being in the context of healthy ageing enhanced by personalised ICT solutions. ${ }^{31}$

\section{Conclusion}

One notable trend that we observed was an ageing population, which is contributed to a lower birth rate births and increased life expectancy. When the number of older adults increases, the risk of dementia increases. Ill individuals are limited in their ability to execute ADL care for themselves, and they are fully dependent on the help of others. This leads to an increase in the number of caregivers required - professional or family members- for everyday tasks. Caregiving and treatment aimed at improving the QoL of affected individuals assume certain costs - direct and indirect.

All the aforementioned information in this paper indicate the need to examine the current state of research regarding the activities that are gradually reduced among patients in dementia, as well as explore the therapies applied in relation to dementia and how they are effective in attempting to improve QoL. Additionally, this provoked the need to summarise the ADLs activities influenced by therapies and examine the treatment costs and care for patients so that recommendations for R\&D could be made to improve both the QoL of people with dementia and cost-saving measures. Therefore, this paper makes several contributions to the research in this field. 
First, compared with the literature, this paper contributes by addressing the reduced ADLs activities in dementia patients in combination with the cost impact and a focus on the improvement of the QoL for affected individuals and their caregivers. Second, we identified the ADLs activities that are gradually reduced in patients with dementias as follows: eating and drinking, dressing, bathing and personal hygiene, use of the toilet, and transport. Third, we identified the need for further research studies to address the impact of current treatments and therapies on the overall QoL of affected individuals.

Moreover, regarding the costs related to caregiving and treatment related to patients with dementia diseases, we conclude that neither the institutional nor the research and scientific approaches fully realise the scope of the problem or provide predictive models. The great identified challenge is that related costs are mostly informal and they vastly degrade the QoL of caregivers, affecting the quality of care and life of patients. Therefore, our recommendation for institutions and the research community is to find ways to adequately value the efforts input into the care and treatment of ill individuals, through strategies and policies and their proper mapping and placement in the real environment.

Finally, to achieve the ultimate goal, that is, to improve the QoL of patients with dementias and their caregivers, we propose relying on technology solutions that recognise the reality of these individuals. In other words, the proposed solutions need to ensure the highest possible levels of independent participation of affected individuals in everyday life, ease the burden caregivers, and produce cost-savings. The clear identification of selected ADLs for older adults with dementia problems, which are essential in patient care and not currently addressed other than by personal care, is a space for researchers across disciplines. A goal to focus on whether it is a breakthrough in the field of therapies, modern technologies, technical solutions, or the development of the interconnection of solutions across disciplines.

\section{Abbreviations}

AD, Alzheimer's disease; ADLs, activities of daily living; ADCS-ADLs, Alzheimer's Disease Cooperative Study Activities of Daily Living; ALS, amyotrophic lateral sclerosis; BPSD, behavioural and psychological symptoms of dementia; BADLs, basic activities of daily living; CDR, clinical dementia rating; CSDD, Cornell Scale for Depression in Dementia; CRPD, Convention on the
Rights of Persons with Disabilities; CTT, classical test theory; DBS, deep brain stimulation; DQoL, dementia quality of life; EF, executive functioning; FAME, The Family Association for Mental Health Everywhere; FTD, frontotemporal dementia/degeneration; GDP, gross domestic product; GDS, global distribution system; GERAS, prospective, multicentre, non-interventional cohort study in France, Germany and the UK; HRQoL, health-related quality of life; ChCI, Charlson Comorbidity Index; IADLs, instrumental activities of daily living; MMSE, Mini-Mental State Examination; NMB, net monetary benefit; NPI, national provider identifier; NPI-Q, Neuropsychiatric Inventory Questionnaire; OTDL-R, observed tasks of daily living; PD, Parkinson's disease; PDD, Parkinson's disease dementia; PwD, people with dementia; QALY, quality-adjusted life-year; QoL, quality of life; QoL-AD, quality of life in Alzheimer's disease; $\mathrm{R} \& \mathrm{D}$, research and development; RMT, Rasch measurement theory; RUD, resource utilisation in dementia; STN, subthalamic nucleus; UN, United Nations; UPDRS, Unified PD Rating Scale; VaD, vascular dementia; WHO, World Health Organization; ZBI, Zarit Burden Interview.

\section{Acknowledgment}

This work is also partially supported by the project IT4Neuro (degeneration), reg. nr. CZ.02.1.01/0.0/0.0/ 18_069/0010054 and by the project of Grant Agency of Excellence, University of Hradec Kralove, Faculty of Informatics and Management, Czech Republic (under ID: UHK-FIM-GE-2020). The authors would like also to acknowledge research laboratory Little Mama Labs, Sarajevo, Bosnia and Herzegovina. We are also grateful for the support of professor Jasmina Baraković Husić in consultation regarding QoL aspects.

\section{Disclosure}

The authors report no conflicts of interest for this work.

\section{References}

1. WHO. 10 facts on ageing and health. WHO. Available from: http:// www.who.int/features/factfiles/ageing/en/. Accessed July 26, 2020.

2. World Population Ageing. 2017. Available from: https://www.un.org/ en/development/desa/population/theme/ageing/WPA2017.asp. Accessed July 26, 2020.

3. Klimova B, Kuca K. Speech and language impairments in dementia. $J$ Appl Biomed. 2016;14(2):97-103. doi:10.1016/j.jab.2016.02.002

4. Kuca K, Maresova P, Klimova B, Valis M, Hort J. Alzheimer's disease and language impairments: social intervention and medical treatment. Clin Interv Aging. 2015;1401. doi:10.2147/CIA.S89714 
5. Maresova P, Klimova B, Novotny M, Kuca K. Alzheimer's and parkinson's diseases: expected economic impact on Europe-a call for a uniform European strategy. J Alzheimers Dis. 2016;54(3):11231133. doi:10.3233/JAD-160484

6. Klimova B, Toman J, Kuca K. Effectiveness of the dog therapy for patients with dementia - a systematic review. BMC Psychiatry. 2019;19(1).doi:10.1186/s12888-019-2245-x

7. Caregiving for Person with Alzheimer's Disease or a related Dementia. Alzheimer's disease and healthy aging. CDC. December 19, 2019. Available from: https://www.cdc.gov/aging/caregiving/alz heimer.htm. Accessed March 7, 2020

8. WHO. Key facts. Key facts. 2019. Available from: https://www.who. int/news-room/fact-sheets/detail/dementia. Accessed March 7, 2020.

9. Baraković S, Baraković Husić J, van Hoof J, et al. Quality of life framework for personalised ageing: a systematic review of ICT solutions. Int J Environ Res Public Health. 2020;17(8):2940.doi:10.3390/ ijerph17082940

10. Bovolenta TM, de Azevedo Silva SMC, Arb Saba R, Borges V, Ferraz HB, Felicio AC. Systematic review and critical analysis of cost studies associated with parkinson's disease. Park Dis. 2017;2017:1-11. doi:10.1155/2017/3410946

11. El-Hayek YH, Wiley RE, Khoury CP, et al. Tip of the iceberg: assessing the global socioeconomic costs of alzheimer's disease and related dementias and strategic implications for stakeholders. $J$ Alzheimers Dis. 2019;70(2):323-341. doi:10.3233/JAD-190426

12. Gooch CL, Pracht E, Borenstein AR. The burden of neurological disease in the United States: a summary report and call to action: burden of neurological disease. Ann Neurol. 2017;81(4):479-484. doi:10.1002/ana.24897

13. Jutten RJ, Dicks E, Vermaat L, et al. Impairment in complex activities of daily living is related to neurodegeneration in alzheimer's disease-specific regions. Neurobiol Aging. 2019;75:109-116. doi:10.1016/j.neurobiolaging.2018.11.018

14. Ritchie K, Lovestone S. The dementias. Lancet. 2002;360 (9347):1759-1766. doi:10.1016/S0140-6736(02)11667-9

15. Novotny M, Klimova B, Valis M. Nitrendipine and Dementia: forgotten positive facts? Front Aging Neurosci. 2018;10. doi:10.3389/ fnagi.2018.00418

16. Yoshida M. Amyotrophic lateral sclerosis with dementia: the clinicopathological spectrum. Neuropathology. 2004;24(1):87-102. doi: $10.1111 /$ j.1440-1789.2003.00544.x

17. Cummings JL. Alzheimer's disease. Wood AJJ, ed. $N$ Engl J Med. 2004;351(1):56-67. doi:10.1056/NEJMra040223

18. Aarsland D, Andersen K, Larsen JP, Lolk A. Prevalence and characteristics of dementia in parkinson disease: an 8-year prospective study. Arch Neurol. 2003;60(3):387. doi:10.1001/archneur.60.3.387

19. Burn DJ, McKeith IG. Current treatment of dementia with Lewy bodies and dementia associated with parkinson's disease. Mov Disord. 2003;18(S6):72-79. doi:10.1002/mds.10566

20. Janvin CC, Larsen JP, Salmon DP, Galasko D, Hugdahl K, Aarsland D. Cognitive profiles of individual patients with parkinson's disease and dementia: comparison with dementia with lewy bodies and alzheimer's disease: cognition in parkinson's disease with dementia. Mov Disord. 2006;21(3):337-342. doi:10.1002/mds.20726

21. Boller F. Aging and Dementia. 2 1. printing. Elsevier; 2001.

22. Joling KJ, Schöpe J, van Hout HPJ, van Marwijk HWJ, van der Horst HE, Bosmans JE. Predictors of societal costs in dementia patients and their informal caregivers: a two-year prospective cohort study. Am J Geriatr Psychiatry. 2015;23(11):1193-1203. doi:10.1016/j.jagp.2015.06.008

23. Clark PG. Quality of life, values, and teamwork in geriatric care: do we communicate what we mean? Gerontologist. 1995;35(3):402-411. doi:10.1093/geront/35.3.402

24. van Hoof J, Beneken Genaamd Kolmer DM, de Vlugt E, de Vries SI. Quality of life: the interplay between human behaviour, technology and the environment. Int J Environ Res Public Health. 2019;16 (24):5106. doi:10.3390/ijerph16245106
25. Post M. Definitions of quality of life: what has happened and how to move on. Top Spinal Cord Inj Rehabil. 2014;20(3):167-180. doi: $10.1310 /$ sci2003-167

26. Hörnquist JO. The concept of quality of life. Scand J Soc Med. 1982;10(2):57-61. doi:10.1177/140349488201000204

27. Marston H. "Who doesn't think about technology when designing urban environments for older people?" A case study approach to a proposed extension of the WHO's age-friendly cities model. Int $J$ Environ Res Public Health. 2019;16(19):3525. doi:10.3390/ ijerph16193525

28. van Hoof J, Kazak J, Perek-Białas J, Peek S. The challenges of urban ageing: making cities age-friendly in Europe. Int $J$ Environ Res Public Health. 2018;15(11):2473. doi:10.3390/ijerph15112473

29. Rajati F, Ashtarian H, Salari N, Ghanbari M, Naghibifar Z, Hosseini S. Quality of life predictors in physically disabled people. $J$ Educ Health Promot. 2018;7(1):61. doi:10.4103/jehp.jehp_115_17

30. Davidson G, Irvine R, Corman M, et al. Measuring the quality of life of people with disabilities and their families.:101.

31. Maresova P, Krejcar O, Barakovic S, et al. Health-related ICT solutions of smart environments for elderly-systematic review. IEEE Access. 2020;8:54574-54600. doi:10.1109/ACCESS.2020.2981315

32. Ettema TP, Dröes R-M, de Lange J, Mellenbergh GJ, Ribbe MW. A review of quality of life instruments used in dementia. Qual Life Res. 2005;14(3):675-686. doi:10.1007/s11136-004-1258-0

33. Chua K-C, Brown A, Little R, et al. Quality-of-life assessment in dementia: the use of DEMQOL and DEMQOL-proxy total scores. Qual Life Res. 2016;25(12):3107-3118. doi:10.1007/s11136-016-1343-1

34. Hendriks AAJ, Smith SC, Black N. DEMQOL and DEMQOL-proxy: a rasch analysis among those diagnosed with dementia. Health Qual Life Outcomes. 2019;17(1). doi:10.1186/s12955-019-1216-8

35. Chua K-C, Böhnke JR, Prince M, Banerjee S. Health-related qualityof-life assessment in dementia: evidence of cross-cultural validity in Latin America. Psychol Assess. 2019;31(10):1264-1277. doi:10.10 37/pas0000743

36. Woods B, O'Philbin L, Farrell EM, Spector AE, Orrell M. Reminiscence therapy for dementia. Cochrane dementia and cognitive improvement Group, ed. Cochrane Database Syst Rev. 2018. doi:10.1002/14651858.CD001120.pub3

37. Harris MA. The relationship between physical inactivity and mental wellbeing: findings from a gamification-based community-wide physical activity intervention. Health Psychol Open. 2018;5(1):205 510291775385. doi:10.1177/2055102917753853

38. Abraha I, Rimland JM, Trotta FM, et al. Systematic review of systematic reviews of non-pharmacological interventions to treat behavioural disturbances in older patients with dementia. The SENATOR-OnTop series. BMJ Open. 2017;7(3):e012759. doi:10.11 36/bmjopen-2016-012759

39. Shlisky J, Bloom DE, Beaudreault AR, et al. Nutritional considerations for healthy aging and reduction in age-related chronic disease. Adv Nutr Int Rev J. 2017;8(1):17.2-26. doi:10.3945/an.116.013474

40. Shaji KS, Sivakumar PT, Rao GP, Paul N. Clinical practice guidelines for management of dementia. Indian J Psychiatry. 2018;60(Suppl 3): S312-S328. doi:10.4103/0019-5545.224472

41. Briggs R, Kennelly SP, O'Neill D. Drug treatments in alzheimer's disease. Clin Med. 2016;16(3):247-253.doi:10.7861/clinmedicine. 16-3-247

42. Frankenstein LL, Jahn G. Behavioral and occupational therapy for dementia patients and caregivers. GeroPsych. 2020;33(2):85-100. doi:10.1024/1662-9647/a000225

43. Gibbor L, Yates L, Volkmer A, Spector A. Cognitive stimulation therapy (CST) for dementia: a systematic review of qualitative research. Aging Ment Health. 2020;1-11.doi:10.1080/13607863. 2020.1746741

44. Orrell M, Yates LA, Burns A, et al. Individual Cognitive Stimulation Therapy for dementia (iCST): study protocol for a randomized controlled trial. Trials. 2012;13(1).doi:10.1186/1745-6215-13-172 
45. Ali A, Brown E, Spector A, Aguirre E, Hassiotis A. Individual cognitive stimulation therapy for people with intellectual disability and dementia: protocol of a feasibility randomised controlled trial. BMJ Open. 2018;8(12):e022136.doi:10.1136/bmjopen-2018-022136

46. Clemmensen TH, Lauridsen HH, Andersen-Ranberg K, Kristensen HK. "I know his needs better than my own" - carers' support needs when caring for a person with dementia. Scand J Caring Sci. 2020. doi: $10.1111 /$ scs. 12875

47. Moher D, Liberati A, Tetzlaff J, Altman DG, The PRISMA Group. Preferred reporting items for systematic reviews and meta-analyses: the PRISMA statement. PLoS Med. 2009;6(7):e1000097.doi:10.1371/ journal.pmed.1000097

48. Leung XY, Sun J, Bai B. Bibliometrics of social media research: a cocitation and co-word analysis. Int J Hosp Manag. 2017;66:35-45 doi:10.1016/j.ijhm.2017.06.012

49. Arksey H, O’Malley L. Scoping studies: towards a methodological framework. Int J Soc Res Methodol. 2005;8(1):19-32.doi:10.1080/ 1364557032000119616

50. Alzheimer Europe - policy - national dementia strategies. Available from: https://www.alzheimer-europe.org/Policy/National-DementiaStrategies. Accessed May 6, 2020.

51. Jennings LA, Laffan AM, Schlissel AC, et al. Health care utilization and cost outcomes of a comprehensive dementia care program for medicare beneficiaries. JAMA Intern Med. 2019;179(2):161. doi:10.1001/jamainternmed.2018.5579

52. Zwicker J, Qureshi D, Talarico R, et al. Dying of amyotrophic lateral sclerosis: health care use and cost in the last year of life. Neurology. 2019;93(23):e2083-e2093.doi:10.1212/WNL.0000000000008582

53. Sopina E, Spackman E, Martikainen J, Waldemar G, Sørensen J. Long-term medical costs of alzheimer's disease: matched cohort analysis. Eur J Health Econ. 2019;20(3):333-342. doi:10.1007/ s10198-018-1004-0

54. Pyenson B, Sawhney TG, Steffens C, et al. The real-world medicare costs of alzheimer disease: considerations for policy and care. $J$ Manag Care Spec Pharm. 2019;25(7):800-809.doi:10.18553/ jmcp.2019.25.7.800

55. Takechi H, Kokuryu A, Kuzuya A, Matsunaga S. Increase in direct social care costs of alzheimer's disease in Japan depending on dementia severity. Geriatr Gerontol Int. 2019;19(10):1023-1029. doi:10.1111/ggi.13764

56. Jönsson L, Jönhagen ME, Kilander L, et al. Determinants of costs of care for patients with alzheimer's disease. Int J Geriatr Psychiatry. 2006;21(5):449-459.doi:10.1002/gps.1489

57. Leicht H, Heinrich S, Heider D, et al. Net costs of dementia by disease stage: net costs of dementia by disease stage. Acta Psychiatr Scand. 2011;124(5):384-395.doi:10.1111/j.1600-0447.20 11.01741.x

58. Gustavsson A, Brinck P, Bergvall N, et al. Predictors of costs of care in alzheimer's disease: a multinational sample of 1222 patients. Alzheimers Dement. 2011;7(3):318-327.doi:10.1016/j.jalz.2010. 09.001

59. Reese JP, Heßmann P, Seeberg G, et al. Cost and care of patients with alzheimer's disease: clinical predictors in german health care settings. J Alzheimers Dis. 2011;27(4):723-736.doi:10.3233/JAD-2011-11 0539

60. Gustavsson A, Cattelin F, Jönsson L. Costs of care in a mild-tomoderate alzheimer clinical trial sample: key resources and their determinants. Alzheimers Dement. 2011;7(4):466-473. doi:10.1016/ j.jalz.2010.06.002

61. Tamás G, Gulácsi L, Bereczki D, et al. Quality of life and costs in parkinson's disease: a cross sectional study in Hungary. Chen R, ed. PLoS One. 2014;9(9):e107704. doi:10.1371/journal.pone.0107704

62. Brüggenjürgen B, Andersohn F, Ezzat N, Lacey L, Willich S. Medical management, costs, and consequences of alzheimer's disease in Germany: an analysis of health claims data. J Med Econ. 2015;18 (6):466-473.doi:10.3111/13696998.2015.1014090
63. Jones RW, Lebrec J, Kahle-Wrobleski K, et al. Disease progression in mild dementia due to alzheimer disease in an 18-month observational study (GERAS): the impact on costs and caregiver outcomes. Dement Geriatr Cogn Disord Extra. 2017;7(1):87-100. doi:10.1159/000461577

64. Reed C, Belger M, Vellas B, et al. Identifying factors of activities of daily living important for cost and caregiver outcomes in alzheimer's disease. Int Psychogeriatr. 2016;28(2):247-259. doi:10.1017/ S1041610215001349

65. Weir S, Samnaliev M, Kuo T-C, et al. Short- and long-term cost and utilization of health care resources in parkinson's disease in the UK: costs of treating PD in UK. Mov Disord. 2018;33(6):974-981. doi: $10.1002 / \mathrm{mds} .27302$

66. Belger M, Haro JM, Reed C, et al. Determinants of time to institutionalisation and related healthcare and societal costs in a community-based cohort of patients with alzheimer's disease dementia. Eur $J$ Health Econ. 2019;20(3):343-355. doi:10.1007/s10198-018-1001-3

67. Giebel CM, Sutcliffe C, Challis D. Activities of daily living and quality of life across different stages of dementia: a UK study. Aging Ment Health. 2015;19(1):63-71. doi:10.1080/13607863.2014.915920

68. Duru Aşiret G, Kapucu S. The effect of reminiscence therapy on cognition, depression, and activities of daily living for patients with alzheimer disease. J Geriatr Psychiatry Neurol. 2016;29(1):31-37. doi:10.1177/0891988715598233

69. Lima-Silva TB, Bahia VS, Carvalho VA, et al. Direct and indirect assessments of activities of daily living in behavioral variant frontotemporal dementia and alzheimer disease. J Geriatr Psychiatry Neurol. 2015;28(1):19-26. doi:10.1177/0891988714541874

70. Barbe C, Morrone I, Wolak-Thierry A, et al. Impact of functional alterations on quality of life in patients with alzheimer's disease. Aging Ment Health. 2017;21(5):571-576. doi:10.1080/13607863.2015.1132674

71. Puente AN, Cohen ML, Aita S, Brandt J. Behavioral ratings of executive functioning explain instrumental activities of daily living beyond test scores in parkinson's disease. Clin Neuropsychol. 2016;30(1):95-106. doi:10.1080/13854046.2015.1133847

72. Giebel CM, Burns A, Challis D. Taking a positive spin: preserved initiative and performance of everyday activities across mild alzheimer's, vascular and mixed dementia: preserved everyday activities across dementia subtypes. Int J Geriatr Psychiatry. 2017;32(9):959967. doi:10.1002/gps.4553

73. Hagell P. Measuring activities of daily living in Parkinson's disease: on a road to nowhere and back again? Measurement. 2019;132:109124. doi:10.1016/j.measurement.2018.09.050

74. Gorecka-Mazur A, Furgala A, Krygowska-Wajs A, Pietraszko W, Kwinta B, Gil K. Activities of daily living and their relationship to health-related quality of life in patients with parkinson disease after subthalamic nucleus deep brain stimulation. World Neurosurg. 2019;125:e552-e562. doi:10.1016/j.wneu.2019.01.132

75. Lopez FV, Ferencz B, Rohl BY, et al. Everyday functioning in parkinson's disease: evidence from the revised-Observed Tasks of Daily Living (OTDL-R). Parkinsonism Relat Disord. 2019;60:167170. doi:10.1016/j.parkreldis.2018.08.026

76. Shepard DS. Cost-effectiveness in health and medicine. By M.R. Gold, J.E Siegel, L.B. Russell, and M.C. Weinstein (eds). New York: oxford University Press, 1996. J Ment Health Policy Econ. 1999;2(2):91-92. doi:10.1002/(SICI)1099-176X(199906)2:2<91::AID-MHP46>3.0.CO;2-I

77. Jönsson B. Ten arguments for a societal perspective in the economic evaluation of medical innovations. Eur J Health Econ. 2009;10 (4):357-359. doi:10.1007/s10198-009-0173-2

78. Evers SMAA, Hiligsmann M, Adarkwah CC. Risk of bias in trialbased economic evaluations: identification of sources and bias-reducing strategies. Psychol Health. 2015;30(1):52-71. doi:10.1080/ 08870446.2014.953532

79. Drost RMWA, van der Putten IM, Ruwaard D, Evers SMAA, Paulus ATG. Conceptualizations of the societal perspective within economic evaluations: a systematic review. Int J Technol Assess Health Care. 2017;33(2):251-260. doi:10.1017/S0266462317000526 
80. Sturkenboom IHWM, Hendriks JCM, Graff MJL, et al. Economic evaluation of occupational therapy in parkinson's disease: a randomized controlled trial: economic evaluation OTIP study. Mov Disord. 2015;30(8):1059-1067. doi:10.1002/mds.26217

81. Hwang AS, Truong KN, Cameron JI, Lindqvist E, Nygård L, Mihailidis A. Co-Designing Ambient Assisted Living (AAL) environments: unravelling the situated context of informal dementia care. Biomed Res Int. 2015;2015:1-12. doi:10.1155/2015/ 720483

82. Lotfi A, Langensiepen C, Mahmoud SM, Akhlaghinia MJ. Smart homes for the elderly dementia sufferers: identification and prediction of abnormal behaviour. J Ambient Intell Humaniz Comput. 2012;3 (3):205-218. doi:10.1007/s12652-010-0043-x
83. Lyons BE, Austin D, Seelye A, et al. Pervasive computing technologies to continuously assess alzheimerâ $€^{\mathrm{TM}} \mathrm{S}$ disease progression and intervention efficacy. Front Aging Neurosci. 2015:7.doi:10.3389/ fnagi.2015.00102

84. Zdravevski E, Lameski P, Trajkovik V, et al. Improving activity recognition accuracy in ambient-assisted living systems by automated feature engineering. IEEE Access. 2017;5:5262-5280.doi:10.1109/ ACCESS.2017.2684913

85. Coduras A, Rabasa I, Frank A, et al. Prospective one-year cost-ofillness study in a cohort of patients with dementia of alzheimer's disease type in Spain: the ECO study. J Alzheimers Dis. 2010;19 (2):601-615. doi:10.3233/JAD-2010-1258

\section{Publish your work in this journal}

Clinical Interventions in Aging is an international, peer-reviewed journal focusing on evidence-based reports on the value or lack thereof of treatments intended to prevent or delay the onset of maladaptive correlates of aging in human beings. This journal is indexed on PubMed Central, MedLine, CAS, Scopus and the Elsevier
Bibliographic databases. The manuscript management system is completely online and includes a very quick and fair peer-review system, which is all easy to use. Visit http://www.dovepress.com testimonials.php to read real quotes from published authors. 